\title{
IMPACTO DA REDUÇÃo do TEOR DE ENXOFRE DA GASOLINA S800 PARA S50 NAS EMISSÕES dA Frota BRASILEIRA
}

\author{
Luiz Carlos Daemme ${ }^{1}$, Renato Penteado ${ }^{1}$, Pedro Caffaro Vicentini ${ }^{2}$, Marcelo Risso Errera ${ }^{3}$ \\ ${ }^{1}$ Instituto de Tecnologia para o Desenvolvimento - LACTEC \\ ${ }^{2}$ PETROBRAS - CENPES \\ ${ }^{3}$ Universidade Federal do Paraná - UFPR
}

E-mails: $\frac{\text { Luiz.Carlos@ lactec.org.br, Renato@ @ lactec.org.br, }}{\underline{\text { Merrera@gmail.com }}} \underline{\text { Pcvicentini@ petrobras.com.br, }}$

\section{RESUMO}

As emissões veiculares estão diretamente ligadas ao nível de tecnologia dos veículos e combustíveis utilizados. A implantação do PROCONVE em 1989 criou um cronograma contínuo da redução das emissões veiculares. Com isso, as indústrias automotiva e petrolífera, passaram por diversas etapas de aperfeiçoamento de seus produtos e tecnologias. Para os veículos do ciclo Otto, a principal tecnologia para o abatimento das emissões é o catalisador, com eficiência superior a 95\% na conversão das emissões de CO, THC e NOX. Porém, para possibilitar o aumento de sua performance em novas fases do PROCONVE, se fez necessária uma redução contínua do teor de enxofre na gasolina, pois esse elemento figura como agente inibidor da eficiência de conversão dos catalisadores automotivos. No ano de 2014 ocorreu uma expressiva redução do limite no teor de enxofre da gasolina comercial brasileira, passando de um máximo de $800 \mathrm{ppmV}$ para $50 \mathrm{ppmV}$. Os benefícios dessa redução nas emissões da frota então circulante não são demonstrados pelos atuais modelos de inventários nacionais, pois seus fatores de emissão são baseados em testes de homologação e conformidade de produção com o combustível padrão em vigência na época. Essa metodologia não capta mudanças que possam ocorrer na emissão da frota circulante em função de uma alteração posterior de sua especificação. O presente artigo, com uso de dados experimentais, estima os ganhos ambientais da redução ocorrida em 2014 do teor de enxofre da gasolina nas emissões de CO, NMHC e NOx na frota circulante de veículos leves de passageiros e de motociclos. Os resultados demonstram uma redução de 6,6, 5,5 e 19,5\%, respectivamente, para o CO, NMHC e NOx nas emissões geradas pela frota de veículos leves de passageiros e motociclos.

\section{INTRODUÇÃO}

No Brasil a preocupação com as emissões veiculares não é recente. Em 1986, o Conselho Nacional do Meio Ambiente (CONAMA), instituiu o Programa de Controle da Poluição do Ar por Veículos Automotores (PROCONVE), que impôs um cronograma para reduzir gradualmente a emissão de poluentes gerados por veículos novos leves e pesados [1]. O Programa foi inspirado nos modelos das legislações pioneiras dos Estados Unidos e Europa [2]. Seguindo a mesma linha, em 2003, foi implantado o PROMOT - Programa de Controle da Poluição do Ar por Motociclos e Veículos Similares, devido ao crescimento expressivo da frota 
dessa classe de veículo automotor [1][3]. A implantação da legislação de controle de emissões resultou em redução significativa nas emissões regulamentadas [4][5].

Como consequência da implantação da legislação, foram necessárias diversas mudanças tecnológicas nos veículos no Brasil, como a adoção de sistemas de injeção eletrônica e uso de conversores catalíticos para redução da emissão de poluentes, dentre outras. O mesmo se aplicou aos combustíveis, que tiveram suas formulações alteradas, como, por exemplo, a redução do teor de enxofre para possibilitar o avanço das tecnologias de conversão dos poluentes por catalisadores [4][6][7].

Observa-se que o principal mecanismo de envenenamento dos catalisadores automotivos é devido ao enxofre presente no combustível e ao fósforo oriundo do óleo lubrificante. Esses compostos reagem com a superfície do catalisador ocasionando a desativação dos sítios e reduzindo sua eficiência de conversão [6][8][9]. Diversos países têm adotado a redução de enxofre nos combustíveis com o objetivo de reduzir sua emissão e buscando maior eficiência dos conversores catalíticos [10]. Nos últimos anos, o Brasil, em sintonia com outros países, efetuou uma redução acentuada dos teores de enxofre nos combustíveis.

A FIGURA 1 apresenta de forma resumida a evolução do teor de enxofre na gasolina comercial e gasolina utilizada para testes de emissões na certificação de veículos dotados de sistema de ignição por centelha. Ainda, na mesma figura, é possível observar, na parte superior a evolução das fases da regulamentação de emissões do PROCONVE/PROMOT para os veículos leves de passageiros e motociclos. Conforme observado na figura no período entre 1998 e 2014, ocorria uma disparidade entre o teor de enxofre da gasolina comercial e gasolina padrão para testes de certificação. Por exemplo, observa-se que para as fases L5 e M3, o combustível para ensaios de certificação possuía uma especificação de 400 ppmV de enxofre enquanto para o combustível comercial a especificação era de 1.000 ppmV, passando a 800 ppmV em 2011.

FIGURA 1 - RESUMO DO TEOR DE ENXOFRE NA GASOLINA NACIONAL

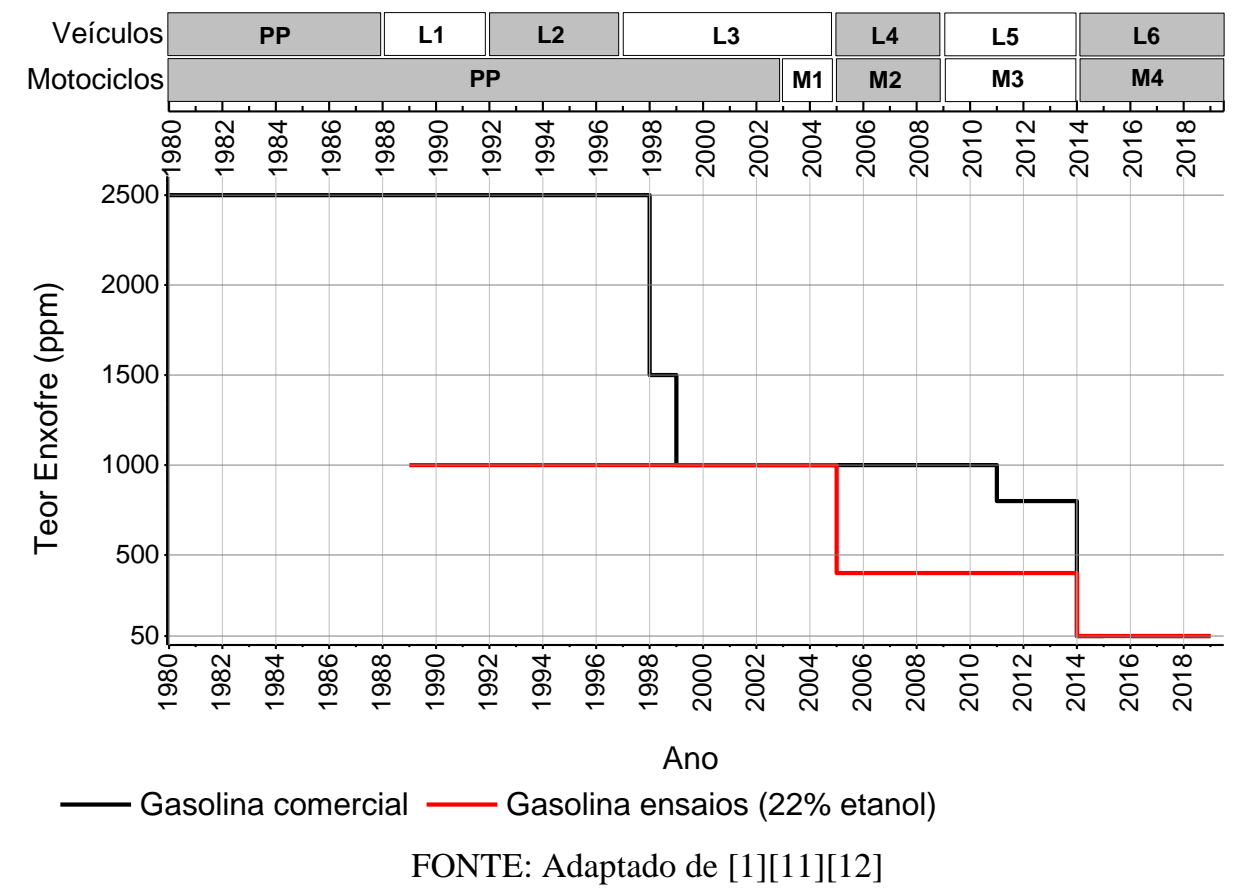


Na FIGURA 2 estão apresentados os valores médios de enxofre na gasolina comercial A para o período 2012 a 2017. Observa-se que o teor de enxofre antes de 2014, com grandes flutuações, estava em um patamar inferior a $50 \%$ do especificado. Entre 2014 e 2015 o valor ficou em torno de 50 ppmV e após 2016, em média, em 30 ppmV.

FIGURA 2 - TEOR DE ENXOFRE NA GASOLINA A COMERCIAL

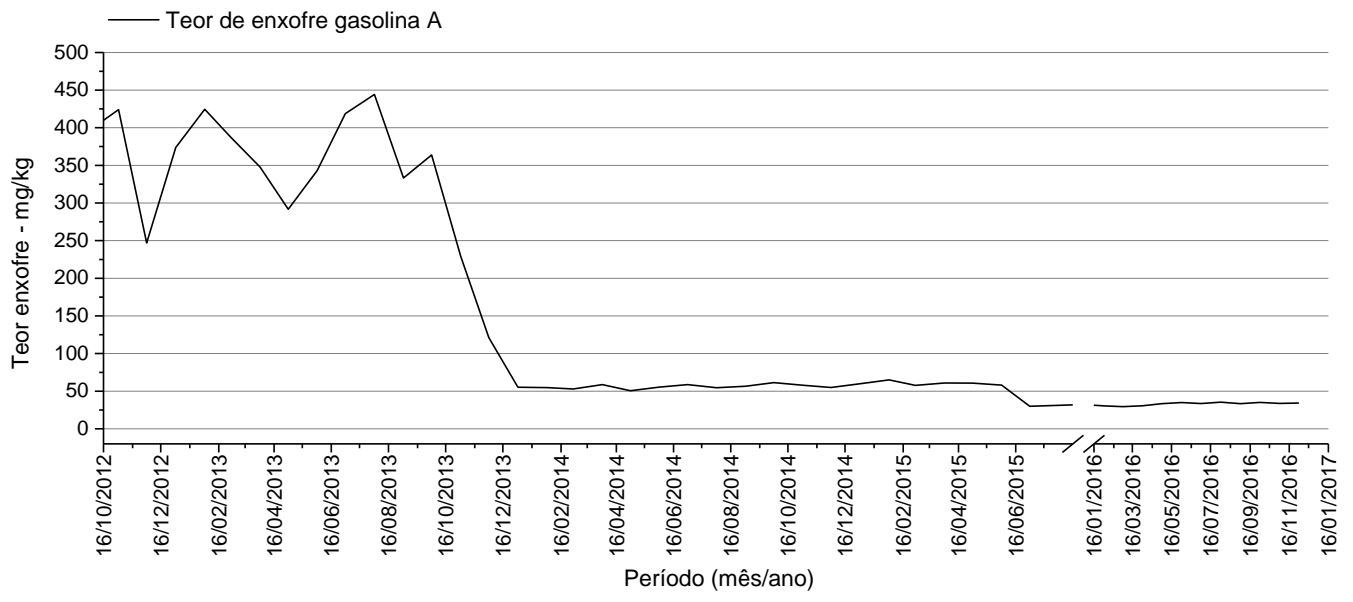

FONTE: Adaptado de [13]

Considerando que, como salientado, o teor de enxofre tem grande influência na eficiência dos catalisadores, diferenças acentuadas entre o teor do contaminante no combustível de referência e comercial podem repercutir no fator de emissão dos principais poluentes.

Nesse contexto, observa-se que isso pode levar a impactos sobre algumas das principais ferramentas para avaliação dos níveis de poluição do ar, como ferramentas de monitoramento da concentração de poluentes, modelagem da dispersão atmosférica e inventários de emissões.

No Brasil o inventário de emissões veiculares é o instrumento mais usado para a avaliação e simulação de cenários envolvendo as tecnologias da frota automotiva e uso de diferentes combustíveis. Com uso dessa ferramenta é possível simular e estimar as emissões veiculares de uma dada região em um determinado período. Ele provê informações importantes para gestores públicos, para pesquisadores e para a sociedade sobre as diferentes fontes e as emissões totais dos componentes em estudo, podendo ser utilizado como instrumento de planejamento estratégico para determinar a atuação na mitigação e controle dos poluentes.

Uma das principais variáveis para determinação dos inventários de emissões veiculares é o fator de emissão. Essa variável é responsável por quantificar as emissões de determinados grupos de veículos, possibilitando o cálculo das massas emitidas de poluentes pelo mesmo.

No Brasil a determinação dos fatores de emissão utilizados na confecção de inventários costuma ser fundamentada na base de dados existente para os ensaios de certificação dos veículos com combustível de referência. Porém, conforme citado, ocorrem discrepâncias entre as especificações do combustível de ensaios e o comercial, sendo que o efeito dessa diferença não é capturado pelos atuais modelos de inventário de emissões.

O presente trabalho tem por objetivo estimar correções aos fatores de emissão em função do teor de enxofre da gasolina comercial, visando reduzir os desvios das estimativas de emissão da frota apresentadas em inventário de emissões veiculares. 


\section{MATERIAIS E MÉTODO}

A correção dos fatores de emissão para cálculo de inventário nacional de emissões propostos por essa pesquisa se fundamentou na realização de testes em laboratório de acordo com os preceitos estabelecidos pela legislação nacional de emissões veiculares e diferentes formulações de gasolina. Os ensaios de emissões em veículos leves e motociclos foram realizados em dinamômetro de chassi seguindo respectivamente a norma NBR 6601 [14] e a Diretiva Europeia $n^{\circ}$ 97/24/EC [15], com medição das emissões de hidrocarbonetos totais (THC), metano, monóxido de carbono $(\mathrm{CO})$, dióxido de carbono $\left(\mathrm{CO}_{2}\right)$ e óxidos de nitrogênio (NOx).

Para o estudo foram selecionados veículos usados de diferentes fases do PROCONVE/PROMOT a partir das fases onde o uso de catalisador foi preponderante, ou seja, para veículos de passageiros para as fases L2 até a fase L5 e para os motociclos da fase M3. Observa-se que os veículos das fases L6 e M4 iniciaram sua vigência concomitante com a adoção da gasolina S50 no mercado. A TABELA 1 apresenta informações gerais sobre as amostras utilizadas para estimar o fator comparativo. Observa-se ainda que foram realizados, em média, três repetições para cada amostra/combustível.

TABELA 1 - INFORMAÇÕES DAS AMOSTRAS UTILIZADAS NOS EXPERIMENTOS

\begin{tabular}{c|c|c|c}
\hline Tipo da amostra & Fase Proconve & $N^{\circ}$ Amostras & Observação \\
\hline Veículos de passageiros & L2 & 03 & - \\
\hline Veículos de passageiros & L3 & 11 & 03 Flex fuel \\
\hline Veículos de passageiros & L4 & 7 & 05 Flex fuel \\
\hline Veículos de passageiros & L5 & 12 & 10 Flex fuel \\
\hline Motociclos & M3 & 10 & 03 Flex fuel \\
\hline
\end{tabular}

Para o programa de experimentos foram utilizadas três formulações de combustíveis, com as especificações apresentadas na TABELA 2. Os combustíveis foram nomeados de A22_S50; A22_S400 e A22_S800 devido aos limites de teor de enxofre que deveriam obedecer, conforme FIGURA 1. Observa-se que foi assumido como premissa do estudo que o combustível S800 como equivalente ao combustível comercial usado até 2013 e para homologações até a fase L3. Ainda a equivalência da gasolina S400 com o combustível de homologação para as fases L4 e L5. Da mesma forma, a gasolina S50 foi considerada equivalente à gasolina comercial S50 usada a partir de 2014 e ao padrão para ensaios de emissões da fase L6. Nesse estudo não foi abordada a existência de diferenças entre os teores de etanol na gasolina de referência e gasolinas comerciais e seus possíveis impactos nas emissões da frota.

TABELA 2 - INFORMAÇÕES DOS COMBUSTÍVEIS UTILIZADOS NOS EXPERIMENTOS

\begin{tabular}{c|c|c|c}
\hline Combustíve & Enxofre & Densidade (kg/L) & Poder calorífico inferior \\
\hline A22 S50 & 30 & 0,743 & 39.054 \\
\hline A22_S400* & 206 & 0,747 & 39.793 \\
\hline A22 S800 & 320 & 0,757 & 38.791 \\
\hline
\end{tabular}

*NOTA: GASOLINA A22_S400 COMBUSTIIVEL PADRÃO DE EMISSÕES (RES. ANP 06/2005).

Foram consideradas os seguintes critérios para definir a necessidade de correções nos fatores de emissão em função da diferença entre o teor de enxofre na gasolina comercial e na de referência:

(1) Os fatores de emissão para os veículos das fases PP (Pré-PROCONVE) e L1, não tiveram correções nos fatores de emissão devido a não ser previsto efeito do teor de 
enxofre nas emissões, pela ausência de sistemas de pós-tratamento (catalisadores) nos veículos.

(2) Para os veículos da fase L2, em que se iniciou o uso de catalisadores automotivos, foi realizada correção nos fatores de emissão após 2013, em decorrência da substituição da gasolina comercial S800 pela gasolina S50 a partir de 2014.

(3) Para fase L3 efetuou-se a mesma correção empregada nos fatores de emissão dos veículos L2, pois a situação era similar.

(4) Para os veículos das fases L4 e L5 foram efetuadas correções dos fatores de emissão para os anos calendário anteriores a 2014, considerando que no período a gasolina comercial (S800) tinha maior teor de enxofre que o da utilizada nos processos de homologação/COP (S400).

(5) Ainda para as fases L4 e L5, a partir de 2014 foi efetuada nova correção nos fatores de emissão, agora para estimar melhora pelo uso comercial de gasolina S50.

(6) Para os veículos da fase L6, não foram empregadas correções devido essa fase ser concomitante com a especificação da gasolina S50 comercial e combustível de ensaios com mesmo teor de enxofre.

(7) Os motociclos anteriores à fase M3 não tiveram correções nos fatores de emissão devido pela ausência de sistemas de pós-tratamento que pudessem ser afetados pela diferença no teor de enxofre da gasolina.

(8) Considerou-se que nos motociclos o uso de sistemas de pós-tratamento com catalisadores iniciou-se apenas a partir da fase M3, que entrou em vigor no ano de 2009 e se estendeu até o ano de 2013. Assim as correções a serem aplicadas aos motociclos dessa fase coincidem com as já citadas para os veículos leves de passageiros da fase L5.

(9) Para os motociclos da fase M4 não foram aplicados fatores de correção, mesmo caso dos veículos L6, devido à utilização de combustível padrão de ensaios com a mesma especificação de enxofre do combustível comercial.

Para propiciar a formulação de um fator de correção a partir da comparação dos resultados de veículos e fases do PROCONVE/PROMOT com os diferentes combustíveis citados, adotou-se um procedimento para padronizar os valores de emissões. Utilizou-se como referência no método o combustível A22-S50, sendo que os resultados individuais das emissões de cada amostra com diferentes combustíveis foram divididos pelo resultado médio obtido com uso de A22-S50. Assim, os resultados de cada amostra foram padronizados com base naqueles obtidos com essa gasolina. Dessa forma, obtém-se um valor de emissão médio igual a uma unidade com uso de A22-S50 e para os demais um fator relativo ao desempenho com esse combustível. Esse fator foi denominado como "fator comparativo".

Os fatores de emissões que foram corrigidos e utilizados para gerar as emissões da frota de veículos de passageiros e motociclos foram os propostos por Daemme [16]. Esses fatores se fundamentam nos dados de emissões do IBAMA, literatura correlata e testes em laboratório com veículos usados de diversos anos de fabricação e tecnologias.

A metodologia para estimar a frota, intensidade de uso e fração de uso de gasolina e etanol para os veículos flex fuel foi obtida com uso da sistemática proposta pelo Inventário de Emissões Veiculares (IEV) [17][18]. No ANEXO A se encontra um resumo dessas informações. Adotouse o intervalo entre os anos de 1980 e 2020 para as previsões de emissões da frota de veículos leves de passageiros e motociclos. Ressalta-se ainda que a frota antes de 1980 foi considerada de acordo com as premissas do IEV [17][18]. 
As FIGURAS 3 e 4 apresentam a composição da frota de veículos leves de passageiros e motociclos, respectivamente, utilizadas para os cálculos das estimativas de emissões por ano calendário. As frotas foram calculadas com dados de vendas (ANEXO A) e taxa de sucateamento de acordo com IEV [17][18].

\section{FIGURA 3 - FROTA DE VEÍCULOS LEVES DE PASSAGEIROS}

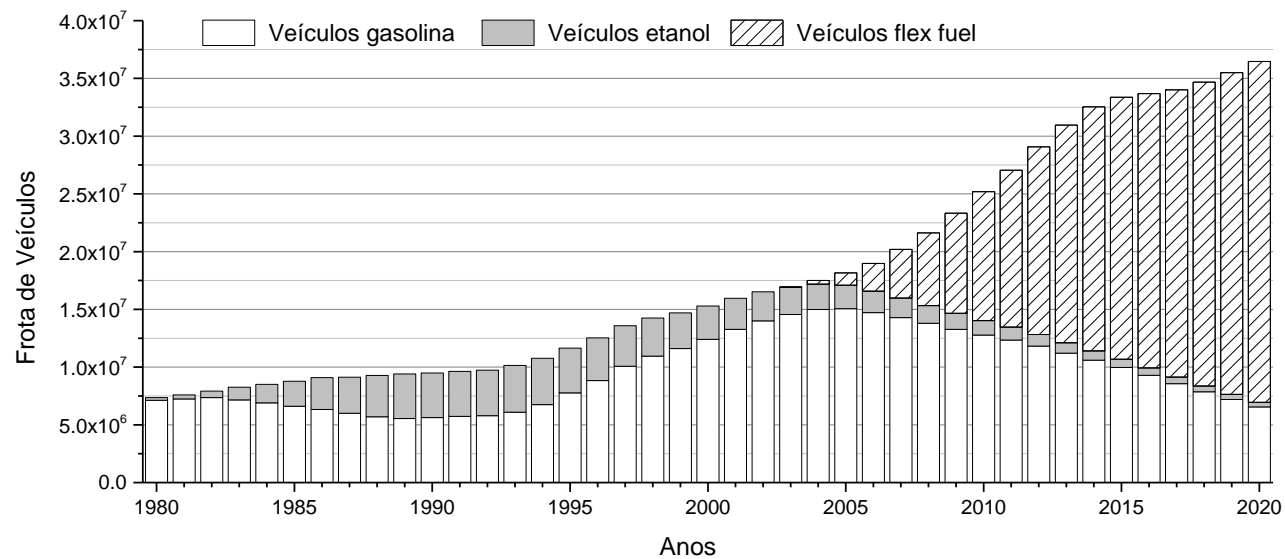

FIGURA 4 - FROTA DE MOTOCICLOS

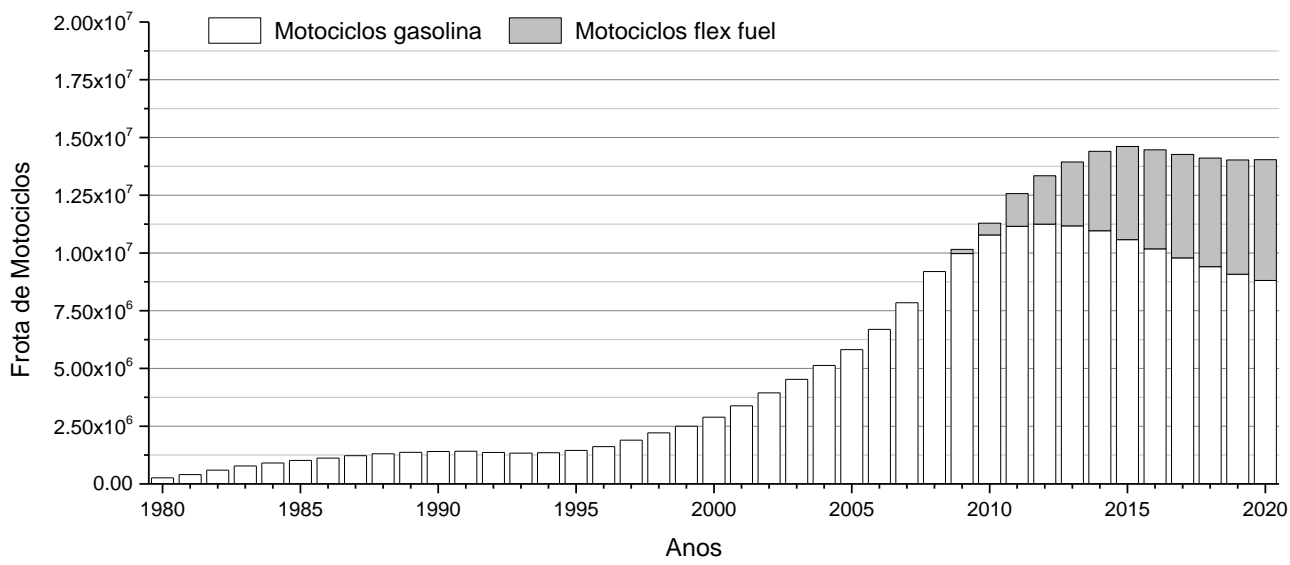

Para comparação estatística entre os fatores gerados foram utilizadas as seguintes ferramentas e premissas: Análise de variância (ANOVA), teste de comparação de médias (TUKEY), teste de poder da amostra (verificação erro tipo II), erro padrão e nível de significância de $5 \%$.

\section{RESULTADOS E DISCUSSÃO}

\subsection{Veículos Leves}

Inicialmente são apresentados os resultados do fator de comparação para os veículos leves de passageiros. As análises para as emissões de $\mathrm{CO}$ nos veículos leves de passageiros são demonstradas na FIGURA 5. Ao lado esquerdo da figura é possível observar os resultados do fator comparativo das emissões de CO para as gasolinas A22_S50, A22_S400 e A22_S800. Como a gasolina S50 foi utilizada como referência na padronização dos resultados, seu fator fica em 1,0. Para gasolina S400 o fator comparativo tem valor de 1,09, ou seja, a emissão com 
esse combustível para o CO é superior em aproximadamente 9\% quando comparada com o combustível S50. A barra de erros ilustrada na figura se refere ao erro padrão. Já para gasolina S800 o fator comparativo fica em 1,26, indicando uma elevação das emissões de CO em aproximadamente $26 \%$ quando comparado à gasolina S50.

Ao lado direito da FIGURA 5 são apresentadas as comparações entre as médias dos fatores comparativos com uso do teste de Tukey. É possível observar que, entre as médias dos fatores comparativos da gasolina A22_S800 e A22_S400, existem diferenças estatísticas (a barra horizontal vermelha não toca o eixo vertical). Para todos os tratamentos efetuados os valores das médias são considerados com diferenças estatísticas significativas.

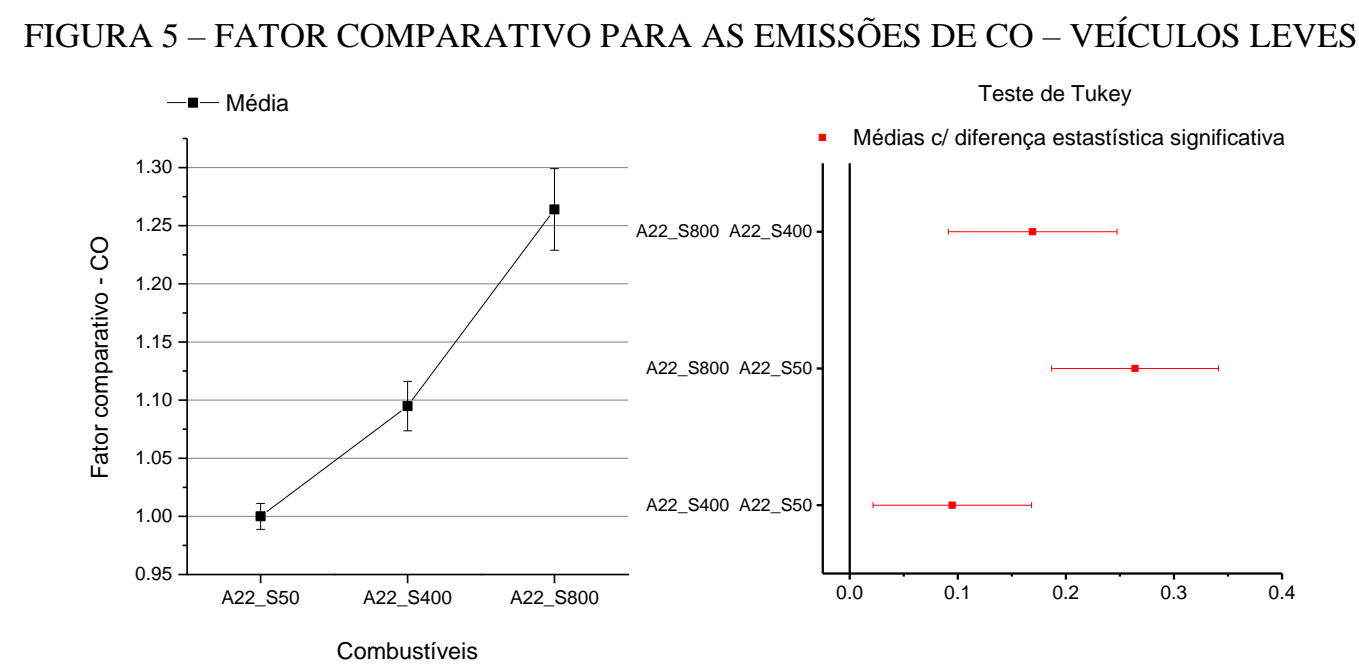

Na FIGURA 6 são apresentados os resultados do fator comparativo para o THC, da mesma forma que foi observado para as emissões de $\mathrm{CO}$, todos os tratamentos são considerados com diferenças estatísticas significativas entre si.

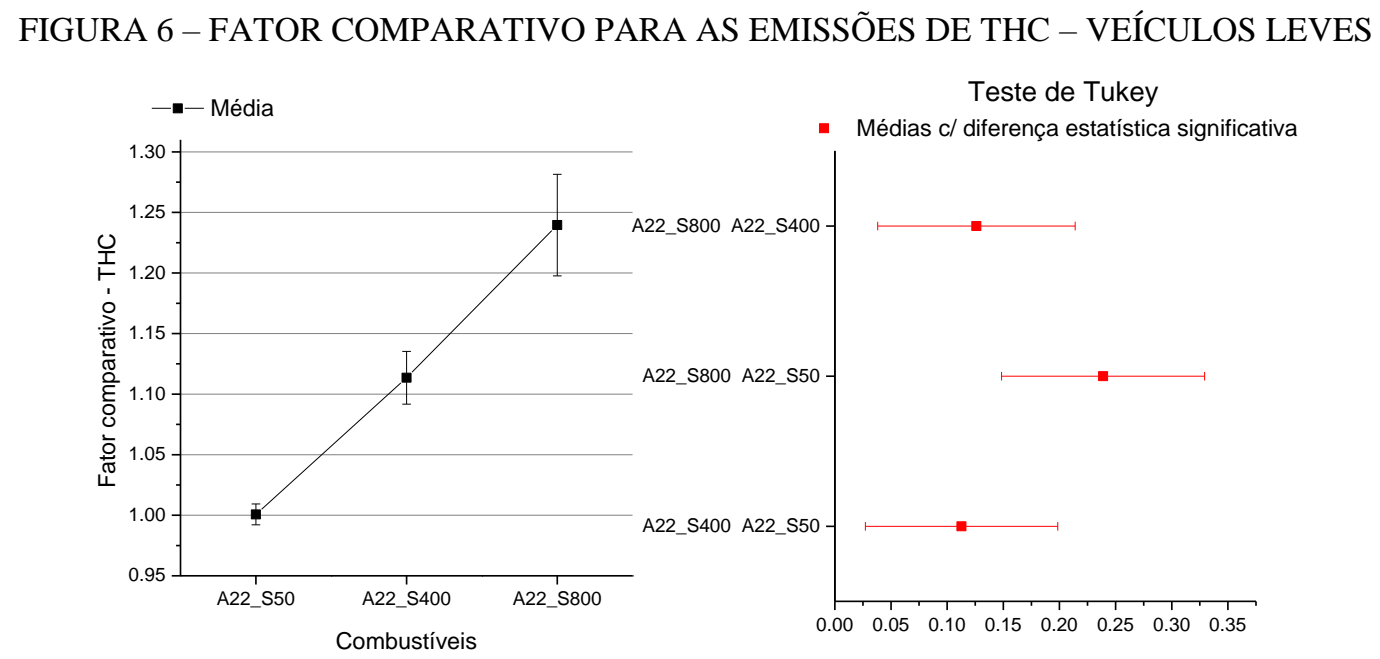

Os fatores comparativos para as emissões de NOx são apresentados na FIGURA 7. É possível observar que em todos os tratamentos existem diferenças estatísticas significativas, ainda o valor do fator comparativo entre as gasolinas S50 e S800 foi de 1,43. Observa-se que para todas 
as análises apresentadas o poder do teste foi superior a 0,96 , demonstrando coerência entre o número de amostras, decisão de rejeitar a hipótese nula e o nível de significância adotado.

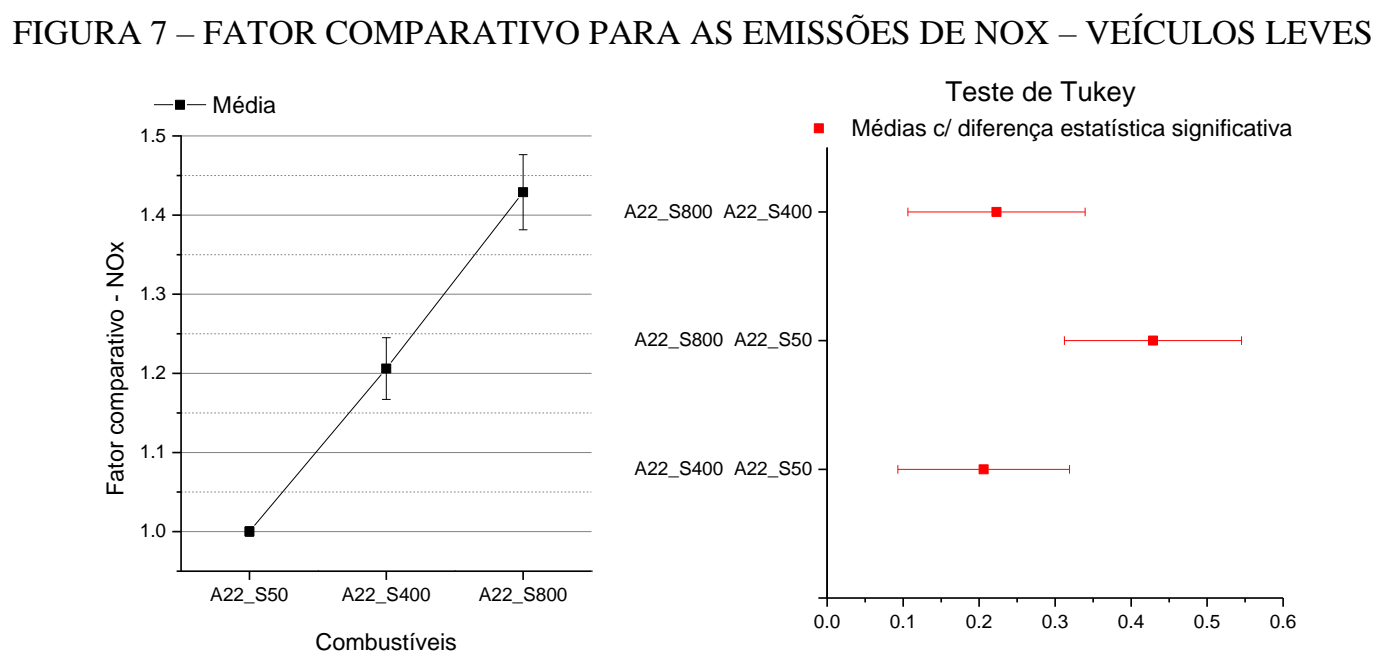

A aplicação das correções aos fatores de emissão foi realizada conforme premissas assumidas para os veículos dedicados à gasolina e para a fração de veículos flex fuel com uso de gasolina. Na FIGURA 8 é possível observar as diferenças em toneladas e porcentual nas emissões de CO devido à implementação da correção proposta. Os resultados foram obtidos calculando-se a emissão da frota de veículos leves de passageiro nacional utilizando gasolina. Em um primeiro momento foram calculadas as emissões dessa frota sem empregar os fatores de correção sugeridos e depois com uso dos fatores. O resultado é a diferença entre os dois métodos. Observa-se que, entre os anos de 2005 e 2013, os valores são positivos na diferença entre os métodos comparados. Esse fato se deve aos veículos das fases L4 e L5 utilizarem gasolina S400 para homologação e conformidade de produção, e os dados dos fatores de emissão serem baseados nesses resultados. Ao corrigir os resultados dos fatores de emissão para a gasolina comercial S800 temos um acréscimo nas emissões gerais dessa frota. Esse aumento representa $4,2 \%$ das emissões da frota geral usando gasolina, cerca de 23.300 toneladas de CO. A partir do ano de 2014 os resultados obtidos são negativos, ou seja, apresentam uma redução nas emissões globais do composto quando comparamos o resultado sem correção com o modelo corrigido. No ano de 2014 temos a maior diferença, aproximadamente $13 \%$ das emissões, que representam uma redução de 73.000 toneladas de $\mathrm{CO}$ para atmosfera. Com o passar dos anos a taxa de redução é minimizada devido à entrada na frota de veículos novos da fase L6, que não impactados pelo fator de correção, pela redução da intensidade de uso dos veículos mais antigos e pelo contínuo sucateamento da frota que tinha seus fatores de emissão corrigidos.

Na FIGURA 9 observamos os resultados obtidos com a comparação dos modelos para o NMHC para frota com uso de gasolina. Observa-se que, para o ano de 2014, a redução na emissão do composto foi de aproximadamente 13\%, representando 8.073 toneladas. 
FIGURA 8 - DIFERENÇAS ENTRE MODELO ATUAL E PROPOSTO - CO

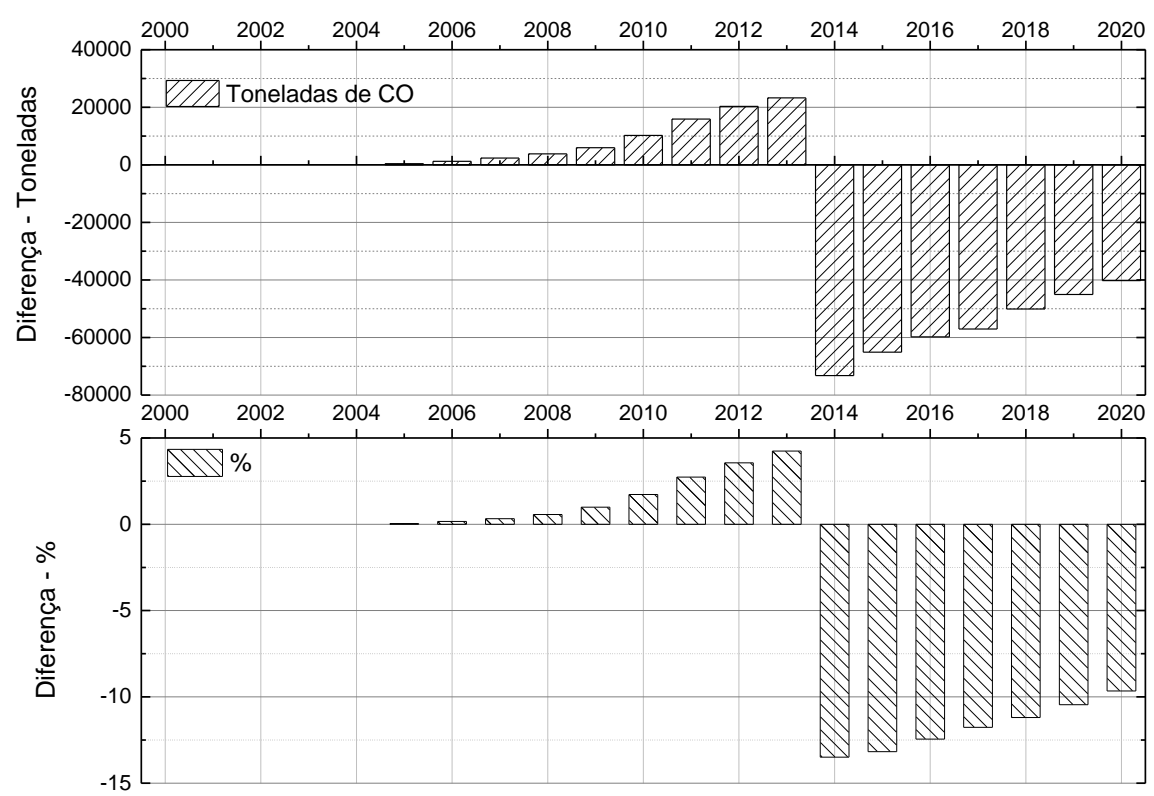

FIGURA 9 - DIFERENÇAS ENTRE MODELO ATUAL E PROPOSTO - NMHC

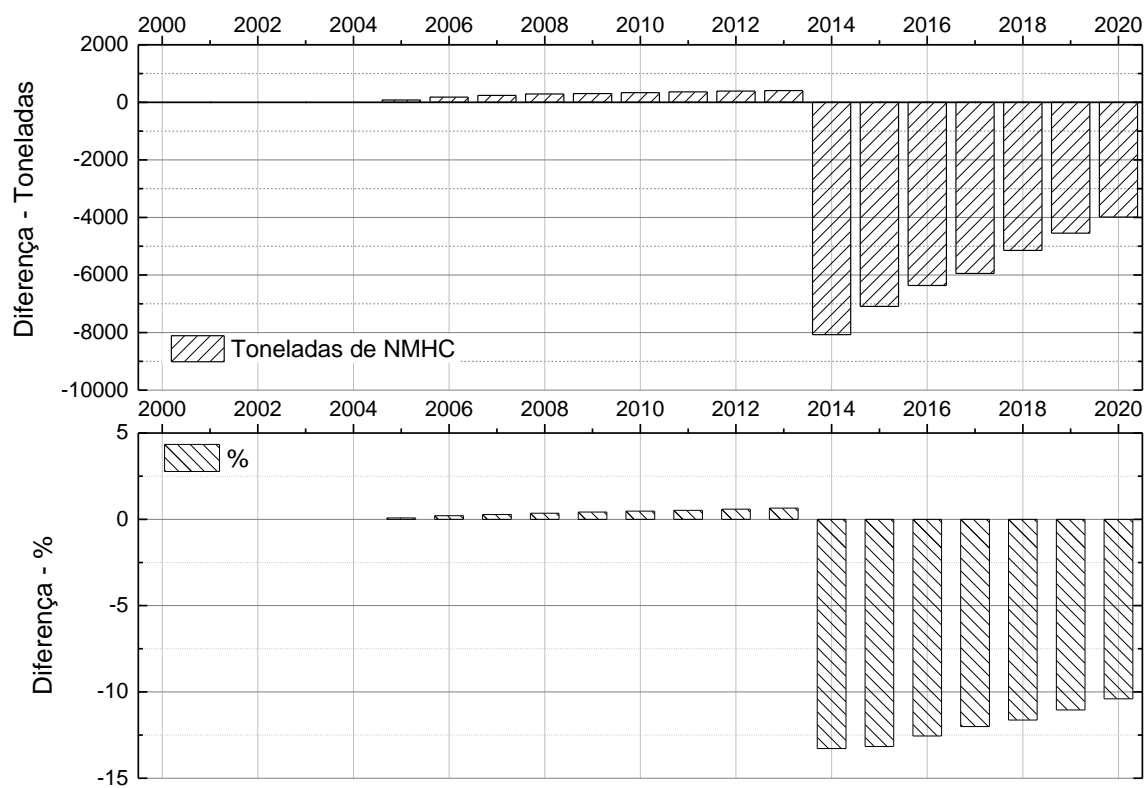

Os resultados obtidos para o NOx estão apresentados na FIGURA 10. Esse composto teve a maior redução observada, cerca de $26 \%$, que representam aproximadamente 20.000 toneladas. 
FIGURA 10 - DIFERENÇAS ENTRE MODELO ATUAL E PROPOSTO - NOX

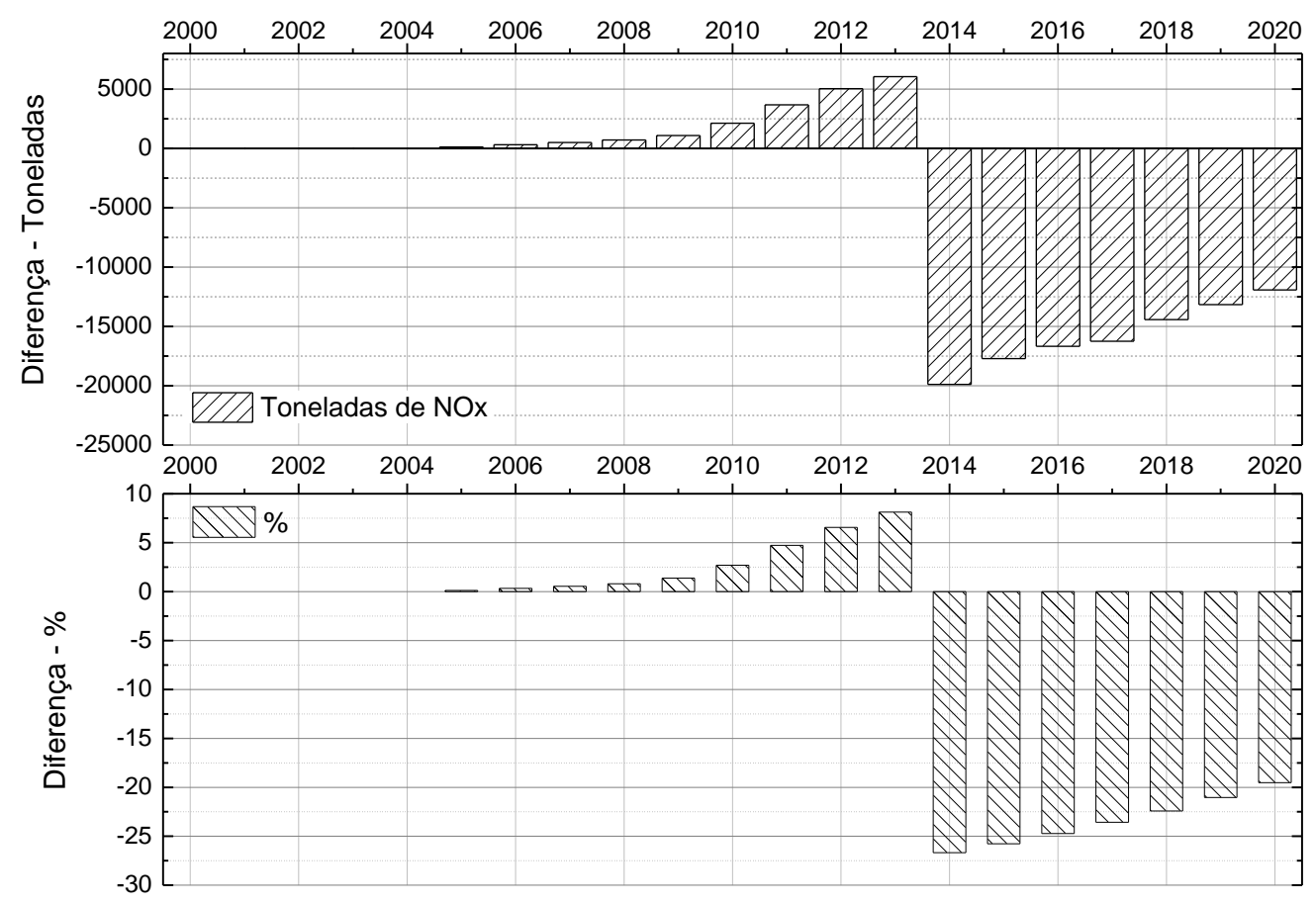

\subsection{Motociclos}

A FIGURA 11 apresenta os valores do fator comparativo para a emissão de CO, observa-se que diferentemente dos resultados em veículos leves de passageiros, em que todos os tratamentos foram considerados diferentes, as médias entre os combustíveis S800 e S400 foram consideradas sem diferenças estatísticas significativas. A magnitude dos fatores comparativos nos motociclos também se apresentaram inferiores aos observados nos veículos leves de passageiros. Esse fato que pode ser atribuído a uma menor precisão de controle na relação ar/combustível nesses veículos [19] reduzindo assim a ação dos catalisadores, ainda, há presença de veículos carburados com uso de apenas de catalisadores de oxidação.

FIGURA 11 - FATOR COMPARATIVO PARA AS EMISSÕES DE CO - MOTOCICLOS
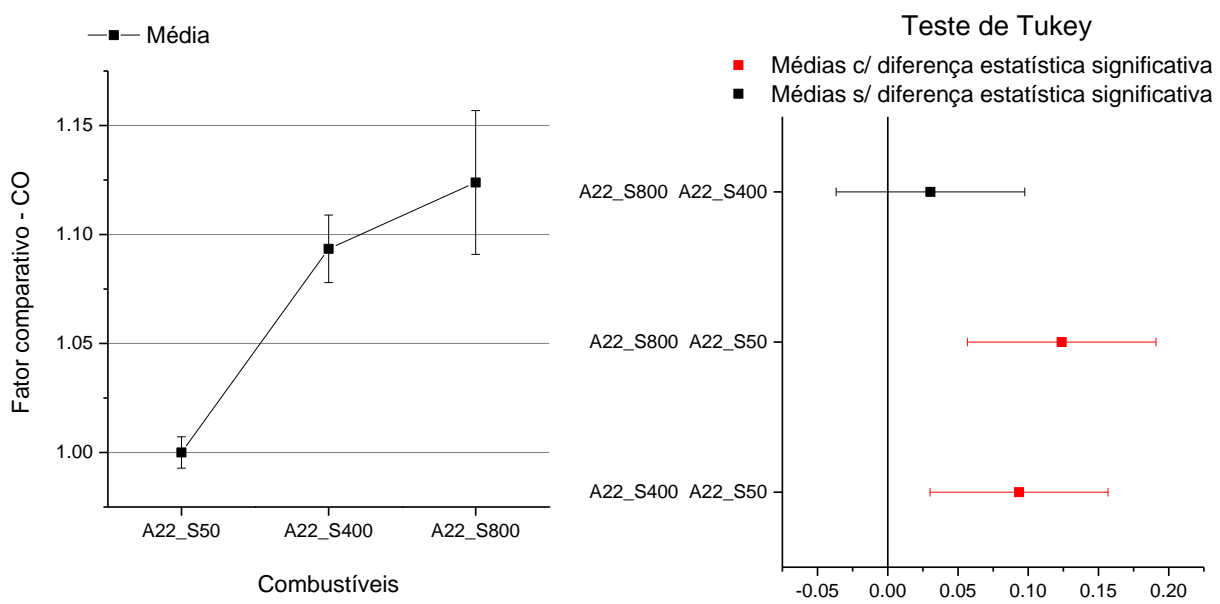
Na FIGURA 12 são apresentados os valores do fator comparativo para as emissões de THC, observa-se que apenas os resultados ente as gasolinas S50 e S800 foram considerados com diferenças estatísticas significativas.

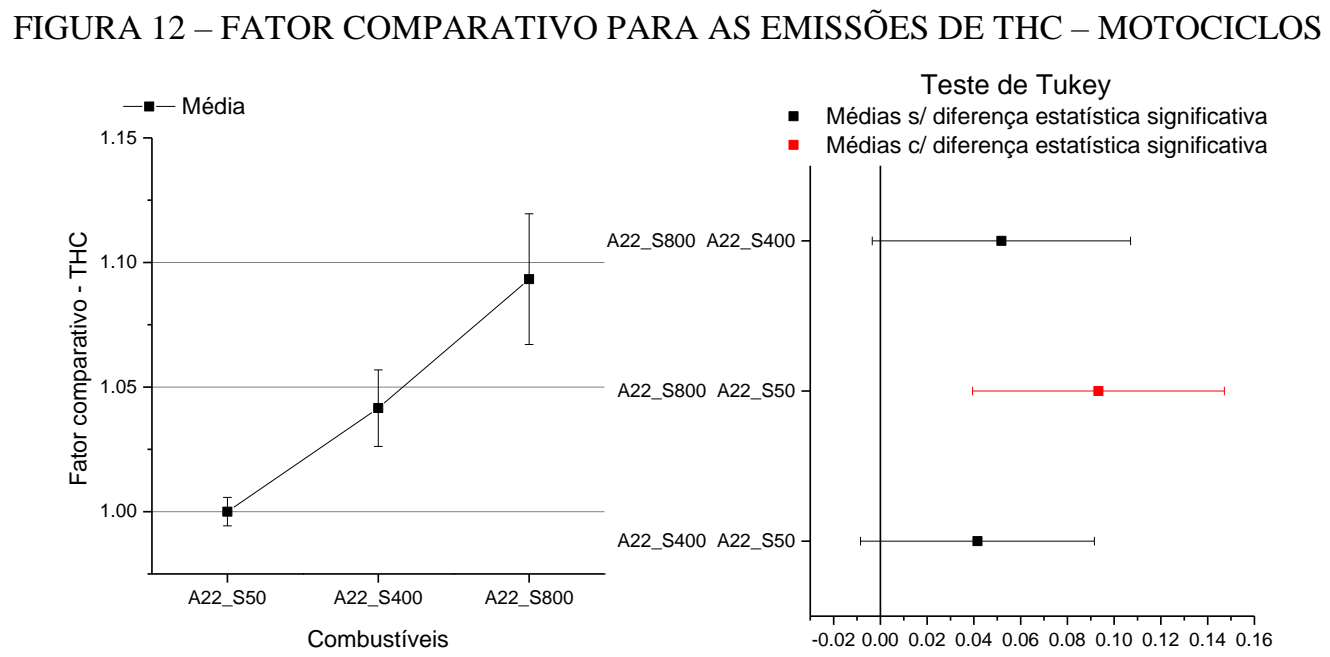

Para as emissões de NOx os resultados são apresentados na FIGURA 13, observando-se que o combustível S800 foi considerado com diferenças significativas quando comparado com as gasolinas S50 e S400.

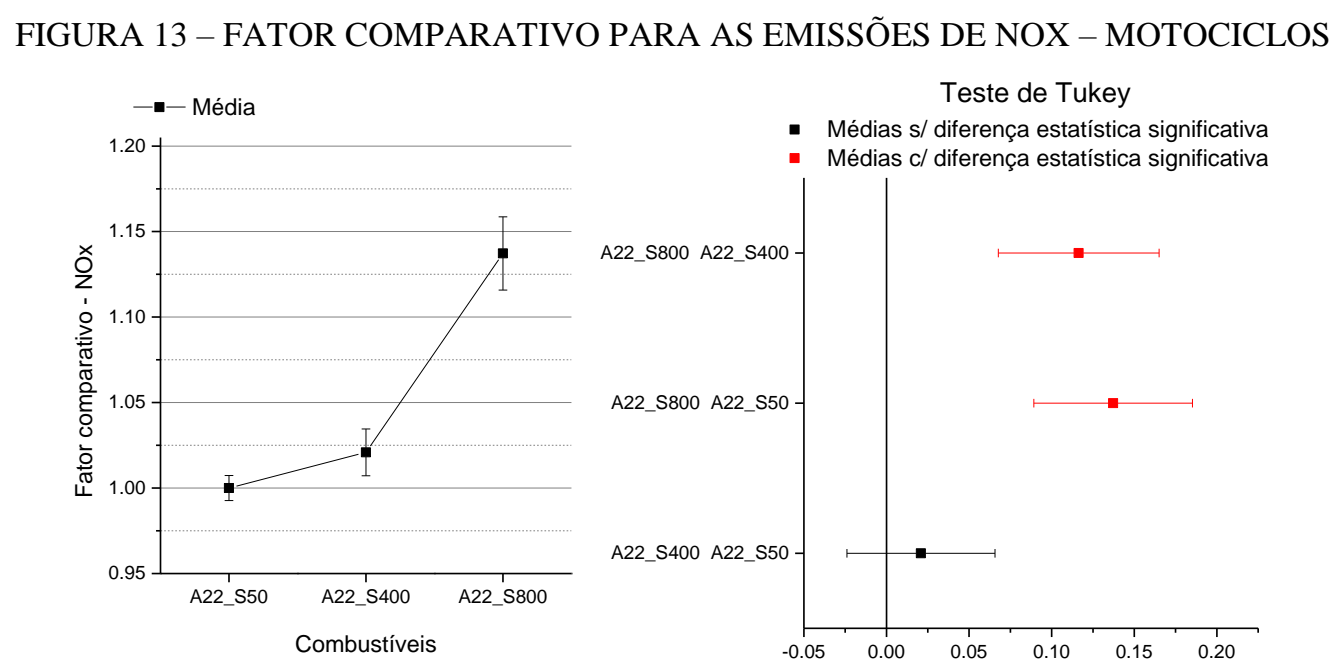

Seguindo o mesmo procedimento adotado para os veículos leves, foram efetuadas as correções das emissões da frota de motociclos com uso de gasolina. Para o NOx foi realizada correção apenas dos fatores de emissão dos motociclos fabricados entre 2009 e 2013 (fase M3), efetuando a correção do uso de gasolina S400 (determinação dos fatores de emissão) para gasolina comercial (S800), correções aplicadas aos anos calendário de 2009 a 2013. Na FIGURA 14 estão demonstrados os valores obtidos com a aplicação do fator de correção, estima-se um aumento nas emissões de NOx de 4,4 \% (727 toneladas), levando-se em consideração a emissão da frota total de motociclos usando gasolina. 
Para as emissões de $\mathrm{CO}$, de acordo com os resultados das comparações dos fatores estimados, foram realizadas correções nas emissões dos motociclos da fase M3 após o ano de 2013, ou seja, passagem dos fatores de emissão calculados com gasolina S400 para o uso de gasolina comercial S50. Os resultados estão demonstrados na FIGURA 14, em que se observa uma redução máxima 2,7 \% (15.319 toneladas) para as emissões de CO no ano de 2019, tendo como referência a emissão da frota total utilizando gasolina.

Quanto às emissões de THC/NMHC dos motociclos não foram realizadas correções devido aos experimentos não demonstrarem diferenças estatísticas significativas entre os combustíveis de homologação (S400) e comercial (S800 e S50).

FIGURA 14 - DIFERENÇAS ENTRE MODELO ATUAL E PROPOSTO - NOx e CO

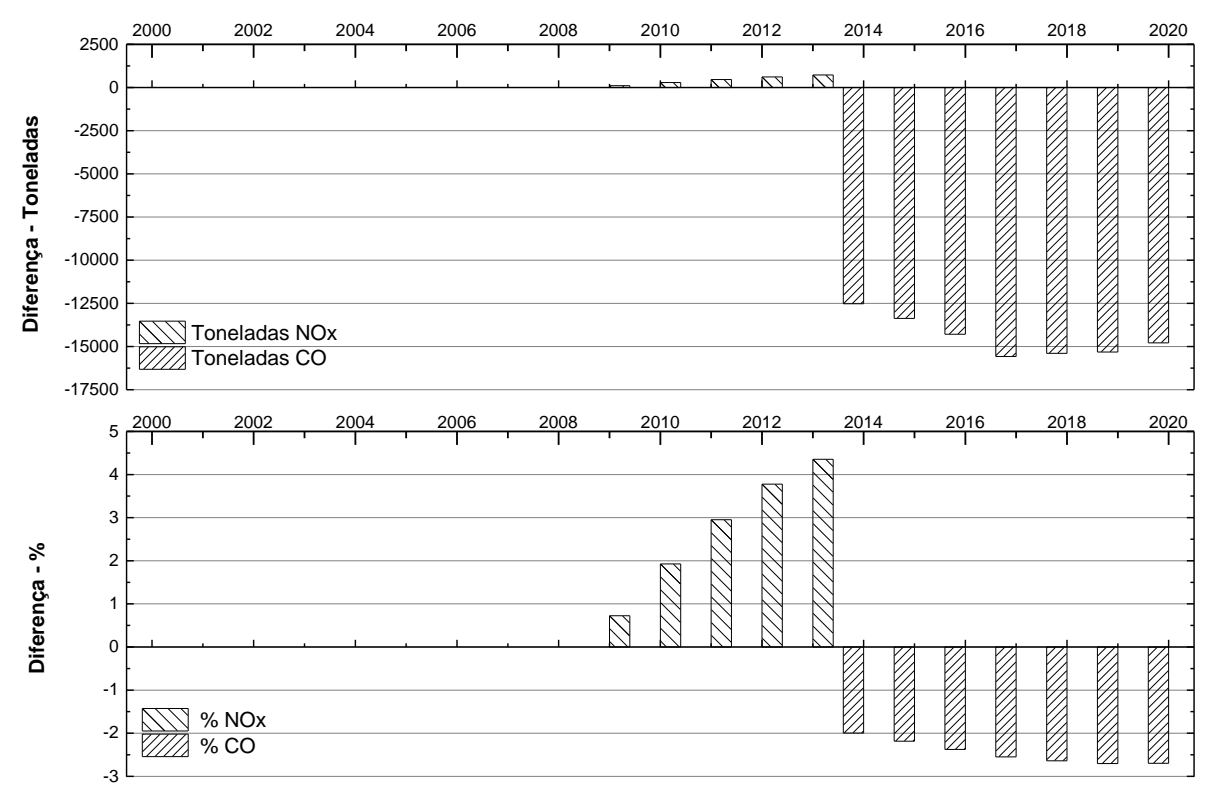

2.3. Cenarização das emissões entre 1980 e 2020

Na FIGURA 15 são estimadas as emissões de CO para frota total de veículos leves de passageiros e motociclos entre 1980 e 2020 com uso de gasolina e etanol. Observa-se que os ajustes propostos para o inventário aumentam em aproximadamente $2 \%$ as emissões gerais da frota para o ano de 2013. Já para o ano de 2014 ocorre uma redução superior a $6 \%$, representando mais de 85.000 toneladas das emissões dessas classes de veículos. Vale ressaltar que nesse estudo está demonstrada a contribuição da redução do teor de enxofre da gasolina comercial para as emissões de CO, NMHC e NOx, sendo os resultados demostrados como se a transição do teor de enxofre se desse de forma única entre os anos de 2013 e 2014. Porém como observado na FIGURA 2 essa transição ocorreu de forma progressiva.

Na FIGURA 16 está apresentado um comparativo das emissões de CO para os veículos leves de passageiros entre a frota gasolina e etanol. Observa-se que entre os anos de 1986 e 1994 uma redução da frota gasolina e, neste mesmo período, uma maior contribuição das emissões de $\mathrm{CO}$ para esse combustível. Após o ano de 1996, até o ano de 2006, observa-se um aumento na participação da frota gasolina e uma redução da participação dessa frota nas emissões gerais de CO. Esses fatos podem ser explicados pela sazonalidade das vendas de veículos etanol 
conforme FIGURA 23 do ANEXO A. Após 2010 a relação frota versus emissão se encontra proporcional, observa-se nesse período a participação expressiva da frota flex fuel.

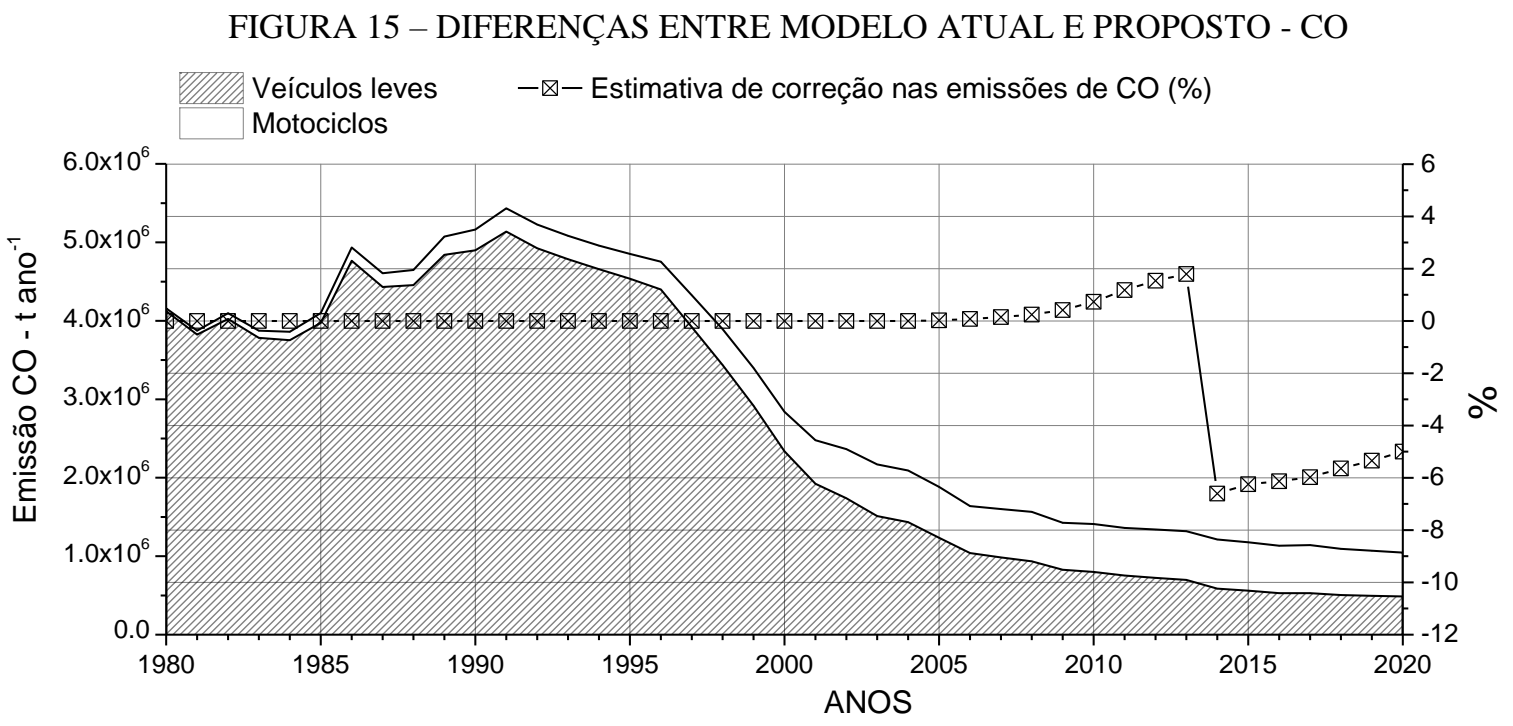

FIGURA 16 - EMISSÃO DE CO POR COMBUSTÍVEL - VEÍCULOS LEVES PASSAGEIROS

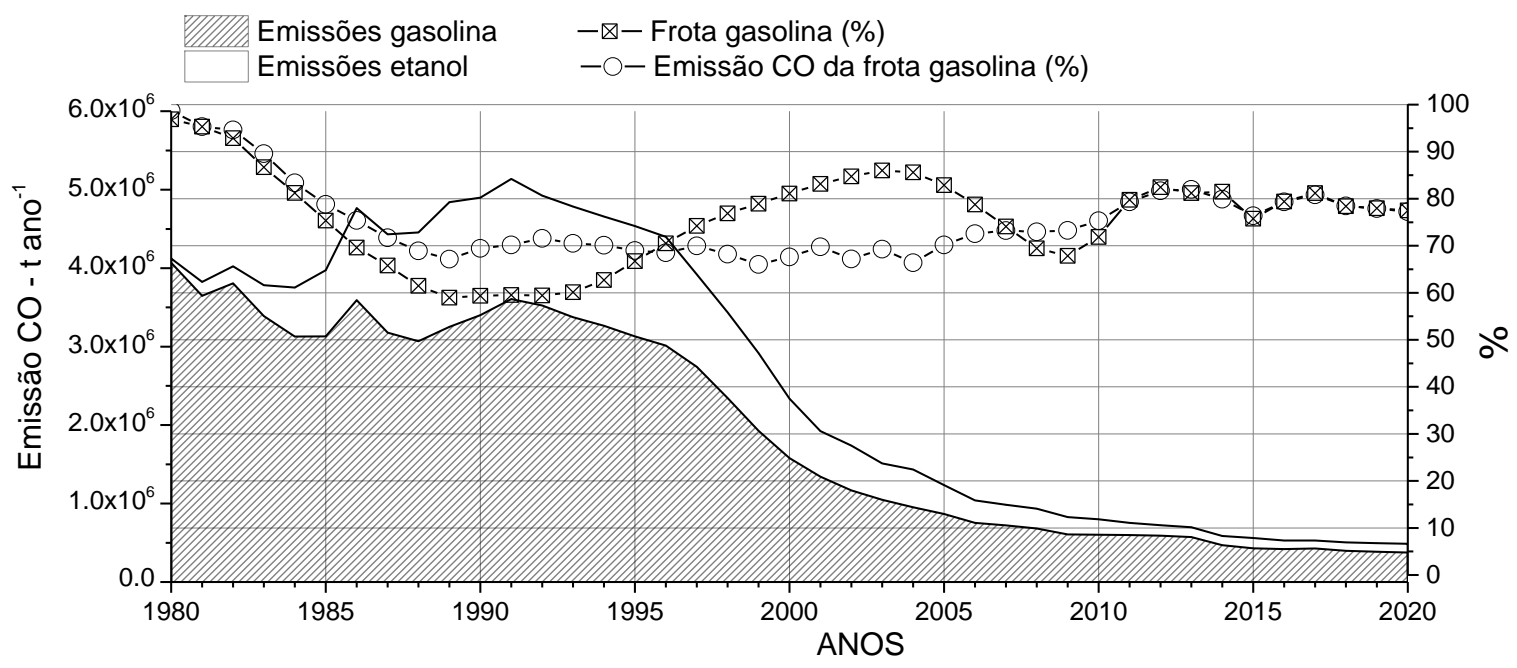

Na FIGURA 17 estão apresentadas as estimativas de emissões de NMHC para frota de veículos leves de passageiros e motociclos. Observa-se que a redução nas emissões globais da frota estudada chega a $6 \%$ para o ano de 2014 , representado cerca de 8.000 toneladas.

Na FIGURA 18 observa-se um comparativo entre a emissão da frota de veículos leves de passageiros e os motociclos para as emissões de NMHC. Observa-se que após o ano de 2001, comparando-se a representatividade da frota de motociclos com suas emissões, a ocorrência de uma elevação significativa das emissões dos motociclos. Para o ano de 2015 a frota de motociclos representava cerca de $30 \%$ da frota total entre motos e veículos de passageiros, porém suas emissões superavam $50 \%$ das emissões totais dessa frota.

Na FIGURA 19 estão apresentadas as comparações entre os modelos para emissão de NOx. Observa-se que o ajuste proposto apresenta um incremento nas emissões do composto para o a ano de 2013 de mais de $5 \%$ das emissões totais da frota circulante de veículos leves de 
passageiros e motociclos. Já para o ano de 2014 é possível observar uma redução de aproximadamente $20 \%$ nas emissões da frota, cerca de 19.000 toneladas.

\section{FIGURA 17 - DIFERENÇAS ENTRE MODELOS - NMHC}

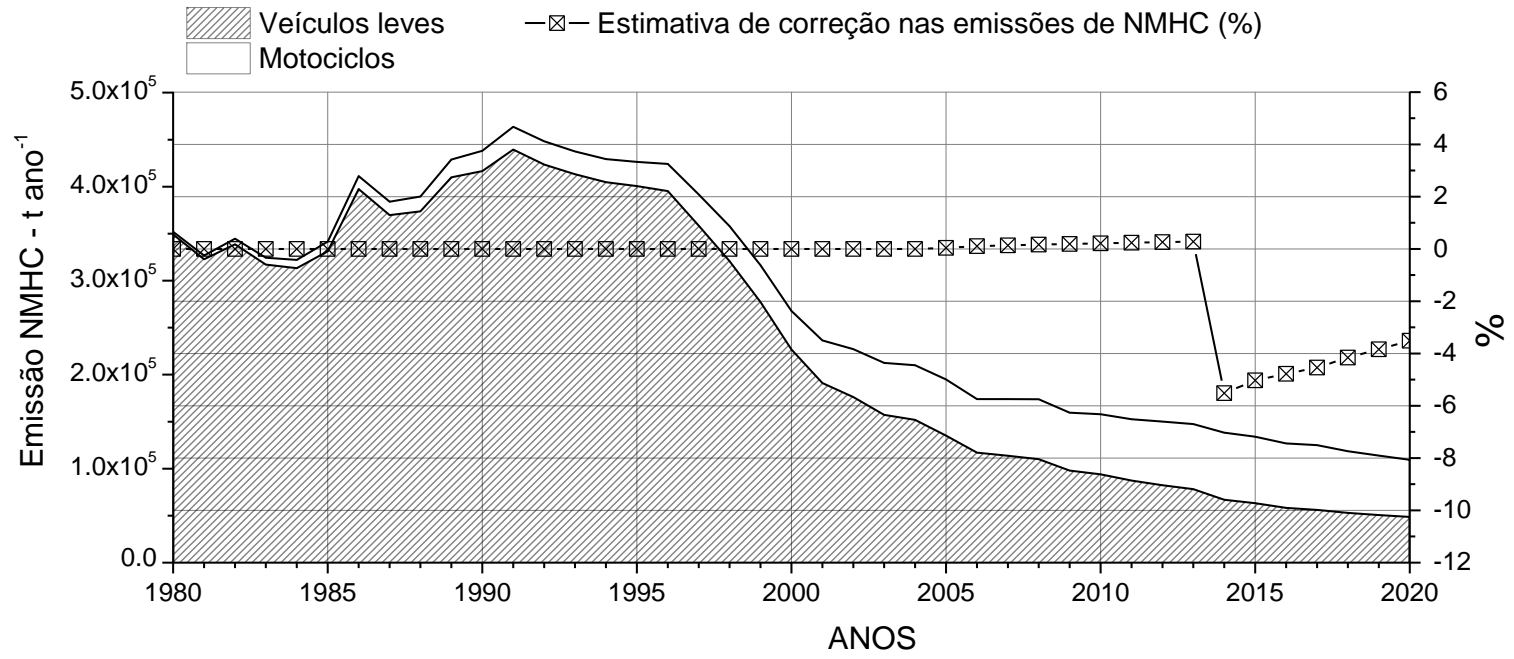

FIGURA 18 - COMPARATIVO ENTRE EMISSÕES DE VEÍCULOS E MOTOCICLOS - NMHC

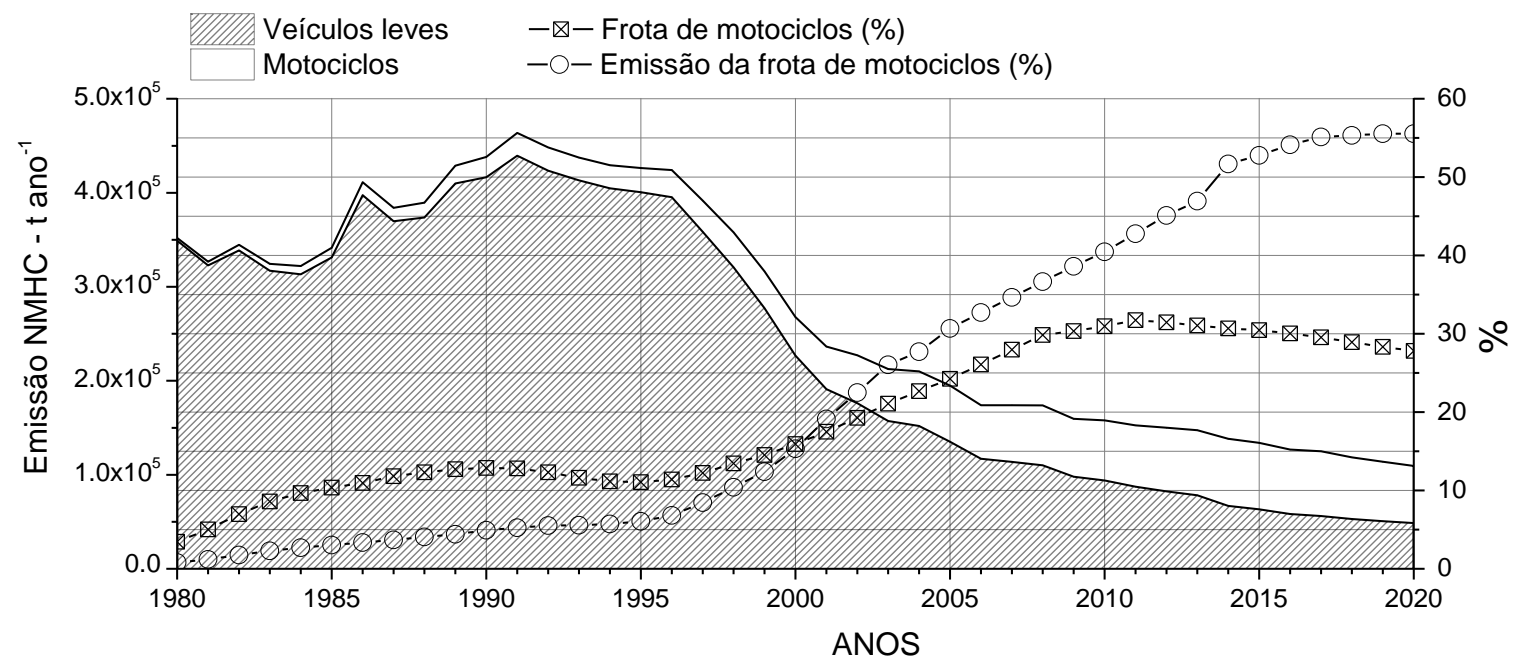

FIGURA 19 - DIFERENÇAS ENTRE MODELOS - NOX

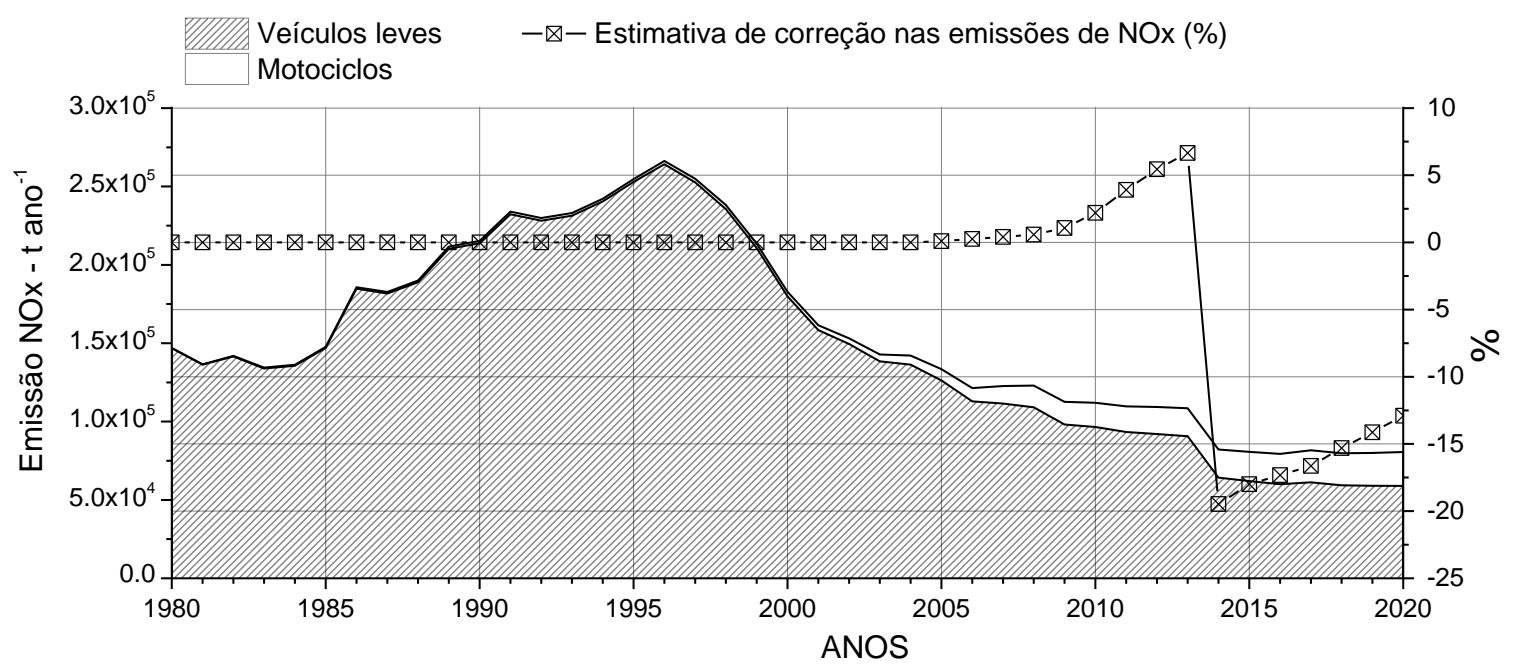


Na FIGURA 20 está apresentado um comparativo entre as emissões de NOx proveniente das frotas de veículos leves de passageiros e motociclos. Observa-se que as emissões do composto durante todo período simulado são inferiores a representatividade da frota para os motociclos. Fato pode estar relacionado a esses veículos operarem com uma relação ar/combustível rica, ou seja, excesso de combustível, favorecendo as emissões de CO e THC. Essa tendência é reduzida, principalmente após o ano de 2010, quando começaram a operar no mercado motociclos com sistemas de injeção eletrônica de combustível. Essa tecnologia permite um melhor controle da relação ar/combustível propiciando uso de catalisadores de três vias, que operam próximos a razão estequiométrica favorecendo as reações de oxidação e redução nos catalisadores.

FIGURA 20 - COMPARATIVO ENTRE EMISSÕES DE VEÍCULOS E MOTOCICLOS - NOX

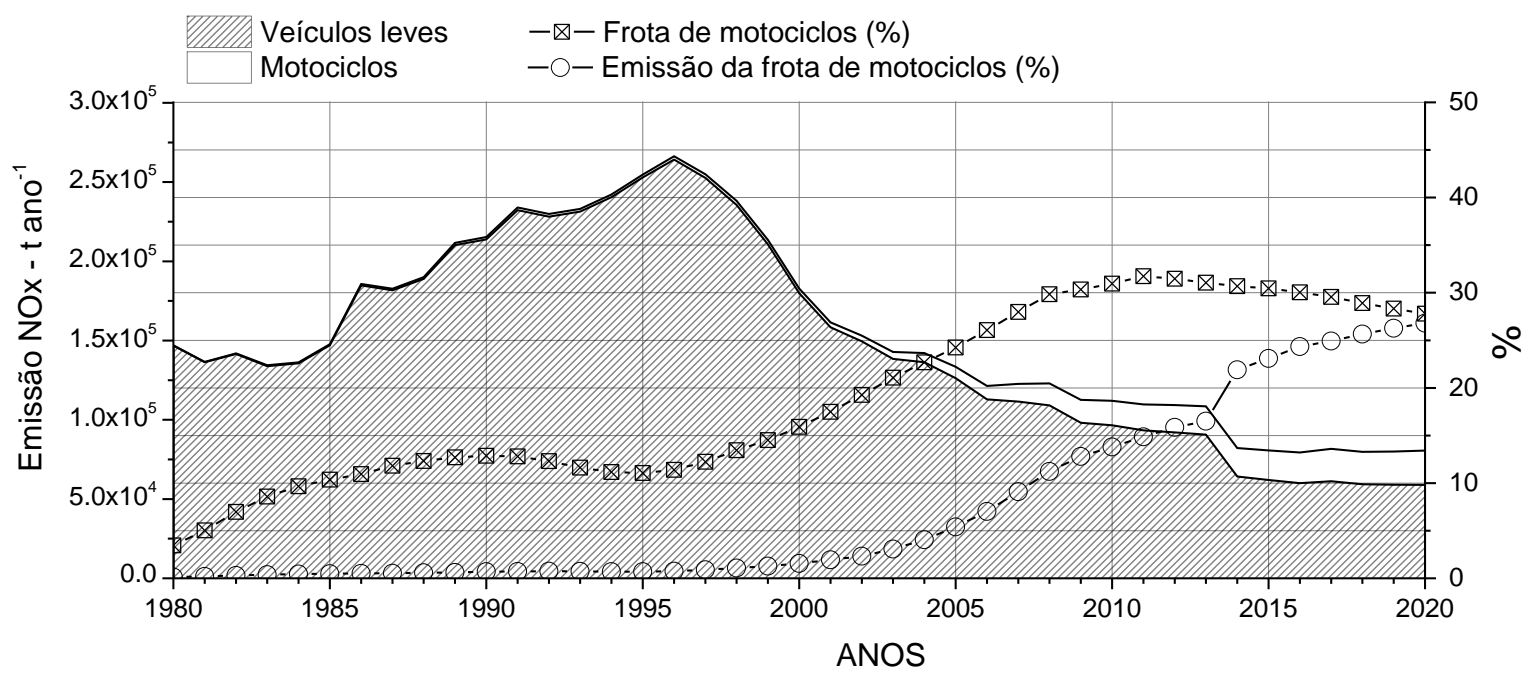

\section{CONCLUSÃO}

Este trabalho investigou o impacto da redução do teor de enxofre das gasolinas S800 e S400 para S50 nas emissões da frota brasileira, ora desconsiderado nos modelos de inventários de emissões das frotas circulantes. O impacto foi investigado com base em ensaios experimentais normatizados e levaram à determinação dos coeficientes de ajustes dos fatores de emissões para os poluentes investigados.

Foram simulados cenários com uso da frota nacional de veículos leves de passageiros e motociclos que permitiram observar os possíveis impactos do uso das correções estimadas no inventário de emissões veiculares. Os resultados demonstram uma redução nas emissões anuais após o ano de 2014. Observou-se, para esse ano de 2014, uma redução de 6,6; 5,5 e 19,5 \%, respectivamente, para o $\mathrm{CO}$, NMHC e NOx nas emissões geradas pela frota de veículos leves de passageiros e motociclos. Tais resultados representam a estimativa de redução do total de emissões na frota, seja para uso de etanol e gasolina.

Um inventário de emissões é uma ferramenta importante para o conhecimento do perfil das emissões da frota veicular de determinado local, ou período, subsidiando tomadas de decisão do poder público sobre políticas relacionadas à legislação de emissões, combustíveis, incentivos fiscais, por exemplo, para renovação de frota, voltadas ao meio ambiente e ao desenvolvimento. 
Os ajustes propostos nesse trabalho podem contribuir para a adoção de novos fatores de emissões que permitam estimativas mais próximas à atual realidade do combustível utilizado pela frota nacional.

\section{AGRADECIMENTOS}

Ao Instituto de Tecnologia para o Desenvolvimento - LACTEC, em especial ao corpo técnico do LEME - Laboratório de Emissões Veiculares pelo apoio prestado ao desenvolvimento da presente pesquisa.

À Agência Nacional do Petróleo - ANP.

Ao Instituto de Energia e Meio Ambiente - IEMA.

Ao Ministério da Ciência e Tecnologia e ao CNPq (Conselho Nacional de Desenvolvimento Científico e Tecnológico) pelo incentivo recebido com a aplicação da Lei 8010/90 nos Laboratórios do LACTEC-LEME.

\section{REFERÊNCIAS}

[1] IBAMA - Instituto Brasileiro do Meio Ambiente e dos Recursos Naturais Renováveis. Programa de controle da poluição do ar por veículos automotores Proconve/Promot/Ibama. 3. ed. Brasília: Ibama/Diqua, 2011. 584 p. (Coleção Meio Ambiente. Série Diretrizes - Gestão Ambiental, n. 3).

[2] MELO, T. C. C. de; COLNAGO, K.; LOUREIRO, L. Implantação dos gases orgânicos do tipo não metano (NMOG) no Brasil. In: SIMPÓSIO INTERNACIONAL DE ENGENHARIA AUTOMOTIVA - SIMEA 2009, 17., 2009, São Paulo. Proceedings...

[3] SILVA, E. R. da; CARDOSO, B. C.; SANTOS, M. P. de S. O aumento da taxa de motorização de motocicletas no Brasil. Revista Brasileira de Administração Científica, v. 2, n. 2, p. 49-63, dez. 2011. ISSN 2179-684X.

[4] SZWARCFITER, L.; MENDES, F. E.; LA ROVERE, E. L. Enhancing the effects of the Brazilian program to reduce atmospheric pollutant emissions from vehicles. Transportation Research Part D: Transport and Environment, v. 10, n. 2, p. 153-160, Mar. 2005. ISSN 1361-9209.

[5] DAEMME, L. C.; PENTEADO, R.; FERREIRA, R. Estudo das emissões de aldeídos geradas em motociclos. In: SIMPÓSIO INTERNACIONAL DE ENGENHARIA AUTOMOTIVA - SIMEA 2010, 18., 2010, São Paulo. Proceedings... São Paulo: AEA, 2010.

[6] RANGEL, M. do C.; CARVALHO, M. F. A. Impacto dos catalisadores automotivos no controle da qualidade do ar. Química Nova, v. 26, n. 2, p. 265-277, 2003. ISSN 0100-4042.

[7] MARTINS, E. M. et al. Atmospheric levels of aldehydes and BTEX and their relationship with vehicular fleet changes in Rio de Janeiro urban area. Chemosphere, v. 67, n. 10, p. 2096-2103, May 2007. ISSN 0045-6535.

[8] BECK, D. D.; SOMMERS, J. W.; DIMAGGIO, C. L. Impact of sulfur on model palladiumonly catalysts under simulated three-way operation. Applied Catalysis B: Environmental, v. 3, n. 2-3, p. 205-227, Feb. 1994. ISSN 0926-3373.

[9] SHELEF, M.; MCCABE, R. W. Twenty-five years after introduction of automotive catalysts: what next? Catalysis today, v. 62, n. 1, p. 35-50, 2000. ISSN 0920-5861.

[10] MEJÍA-CENTENO, I.; CASTILLO, S.; FUENTES, G. A. Enhanced emissions of NH3, $\mathrm{N} 2 \mathrm{O}$ and $\mathrm{H} 2$ from a Pd-only TWC and supported Pd model catalysts: light-off and sulfur 
level studies. Applied Catalysis B: Environmental, v. 119-120, p. 234-240, May 2012. ISSN 0926-3373.

[11] ANP. Agência Nacional de Petróleo. Teor médio de enxofre na gasolina brasileira. 2014. Disponível em: <www.anp.gov.br/anexos/.../graficos_teor_de_enxofre.docx>.

[12]CETESB - Companhia Ambiental do Estado de São Paulo. Emissão Veicular Combustíveis. 2013b. Disponível em: <http://cetesb.sp.gov.br/veicular/combustiveis>.

[13] ANP. Agência Nacional de Petróleo. Teor de enxofre na gasolina A entre 2009 e 2019. Informação do sistema fale conosco ANP. Disponível em: 〈http://www.anp.gov.br/wwwanp/fale-conosco>.

[14] ABNT - Associação Brasileira de Normas Técnicas. NBR 6601: Veículos rodoviários automotores leves - Determinação de hidrocarbonetos, monóxido de carbono, óxidos de nitrogênio, dióxido de carbono e material particulado no gás de escapamento. Rio de Janeiro, 2012.

[15]EC - European Union. European Parliament, Council of the European Union. Directive 97/24/EC of the European Parliament and of the Council of 17 June 1997 on certain components and characteristics of two or three-wheel motor vehicles. Official Journal of the European Communities, L 226, v. 40, 18 Aug. 1997.

[16] DAEMME, L. C. Modelo para determinação de fatores de emissão em veículos leves de passageiros e motociclos. Tese (Doutorado) - Programa de Pós-Graduação em Engenharia de Recursos Hídricos e Ambiental, Universidade Federal do Paraná, Curitiba, Brasil, 2017.

[17] MMA - MINISTÉRIO DO MEIO AMBIENTE. I Inventário Nacional de Emissões Atmosféricas por Veículos Automotores Rodoviários. 2011. Disponível em: <http://www.mma.gov.br/estruturas/163/_publicacao/163_publicacao27072011055200.pd f>.

[18] MMA - MINISTÉRIO DO MEIO AMBIENTE. Inventário Nacional de Emissões Atmosféricas por Veículos Automotores Rodoviários. 2014. Disponível em: <http://www.mma.gov.br/images/arquivo/80060/Inventario_de_Emissoes_por_Veiculos Rodoviarios_2013.pdf>.

[19]CHAN, C.-C. et al. Comparison of tail-pipe emissions from motorcycles and passenger cars. Journal of the Air \& Waste Management Association, v. 45, n. 2, p. 116-124, 1995. ISSN 1096-2247.

[20]ANFAVEA. Associação Nacional dos Fabricantes de Veículos Automotores. Disponível em: < http://www.anfavea.com.br/estatisticas.html $>$. Acesso 17/05/19.

[21]ABRACICLO. Associação Brasileira dos Fabricantes de Motocicletas, Ciclomotores, Motonetas, Bicicletas e Similares. Anuário da indústria brasileira de duas rodas - 2018 . Disponível em: http://www.abraciclo.com.br/anuario-de-2018>, acesso 17/05/19.

\section{ANEXO A}

Para determinação da emissão dos compostos em estudo utilizou-se a equação 1 [17][18]:

$E=F_{r} \times I_{u} \times F_{e}$

Sendo E - taxa de emissão no período inventariado $\left(\mathrm{g}^{\mathrm{ano}}{ }^{-1}\right)$; $\mathrm{Fr}$ - frota circulante de veículos ano-modelo considerado (número de veículos); Iu - intensidade de uso do veículo do anomodelo considerado, expressa em termos de quilometragem anual percorrida $\left(\mathrm{km} \mathrm{ano}^{-1}\right) ; \mathrm{Fe}-$ fator de emissão do poluente considerado, expresso em termos de massa de poluentes emitida por $\mathrm{km}$ percorrido (gpoluente $\mathrm{km}^{-1}$ ). 
Os dados de intensidade de uso da frota necessitam de correções para se adequar às estimativas de distâncias percorridas com o volume de combustível comercializado no período. A FIGURA 21 apresenta os dados de correção dos valores padrão de intensidade de uso conforme IEV. Os dados foram obtidos junto aos inventários [17][18] e informações fornecidas pelo IEMA Instituto de Energia e Meio Ambiente. Para os anos de 2018 a 2020 esses valores de correção foram assumidos como sendo a média dos últimos cinco anos.

FIGURA 21 - CORREÇÃO DA INTENSIDADE DE USO

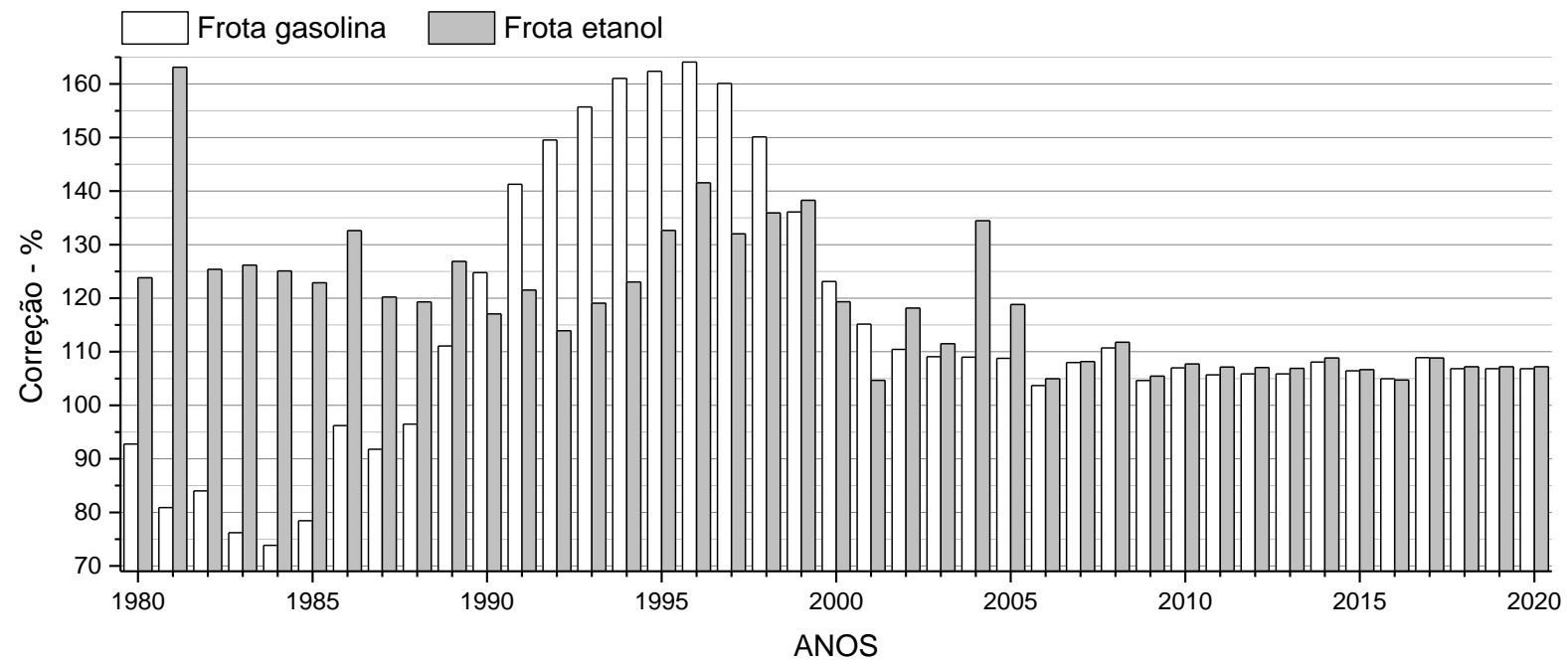

Para os veículos flex fuel, seguindo a premissa de distancias percorrida e volume de combustível vendido em dado período, se faz necessário o ajuste da porcentagem da frota utilizando gasolina e etanol. A FIGURA 22 apresenta essa divisão da frota utilizando gasolina e etanol, as informações são do IEV [17][18] e IEMA - Instituto de Energia e Meio Ambiente. Para os anos de 2018 a 2020 foi utilizada a média dos últimos cinco anos para estimar esse parâmetro.

FIGURA 22 - DIVISÃO DO USO DE GASOLINA E ETANOL NA FROTA FLEX FUEL

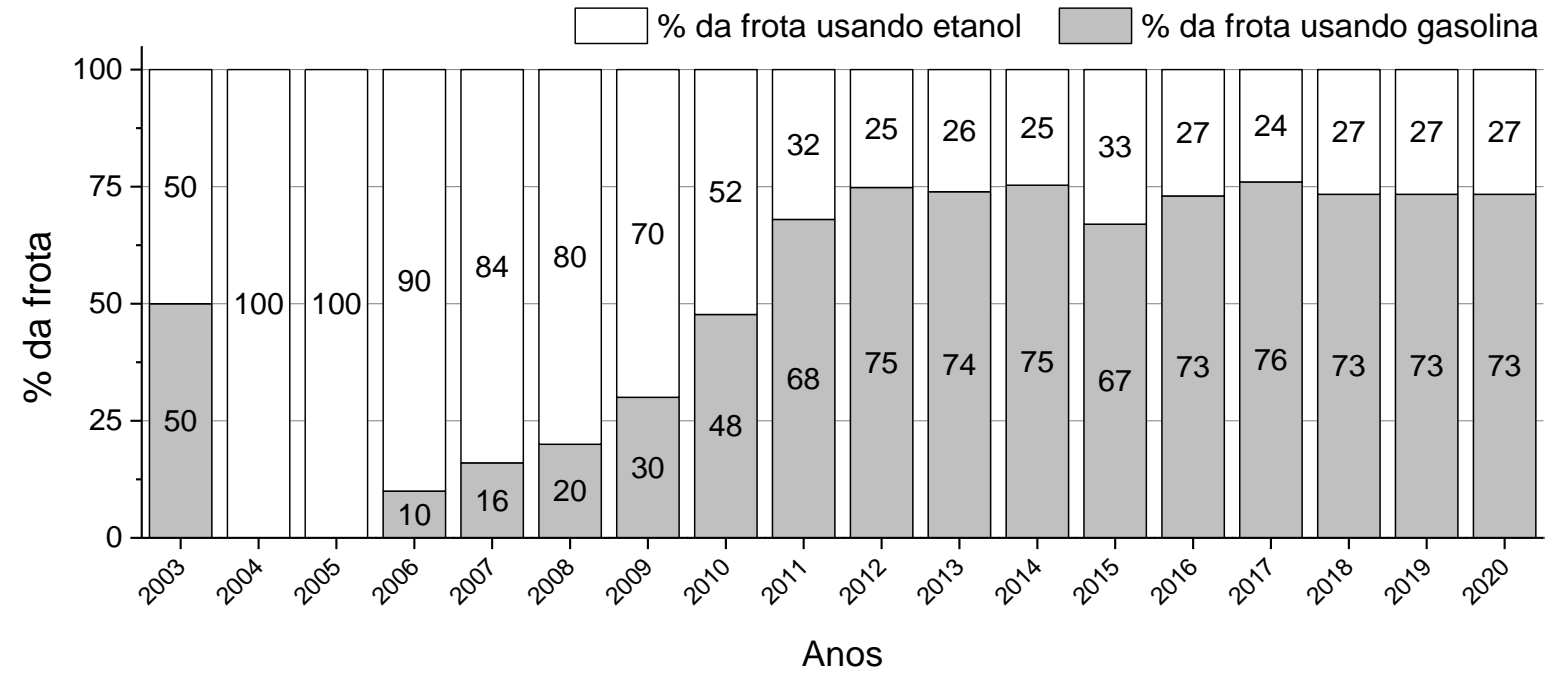

Para composição da frota, utilizando as premissas do IEV, foram utilizados os dados de vendas de veículos leves de passageiros e motociclos. As informações de vendas foram obtidas no IEV [17][18], informações do IEMA, site da ANFAVEA [20] e ABRACICLO [21]. Observa-se que 
para os anos de 2019 e 2020 foi utilizada uma estimativa de vendas, considerando um acréscimo de $10 \%$ sobre os valores do ano anterior. As FIGURAS 23 e 24 apresentam as informações de vendas para os veículos leves de passageiros e motociclos, respectivamente.

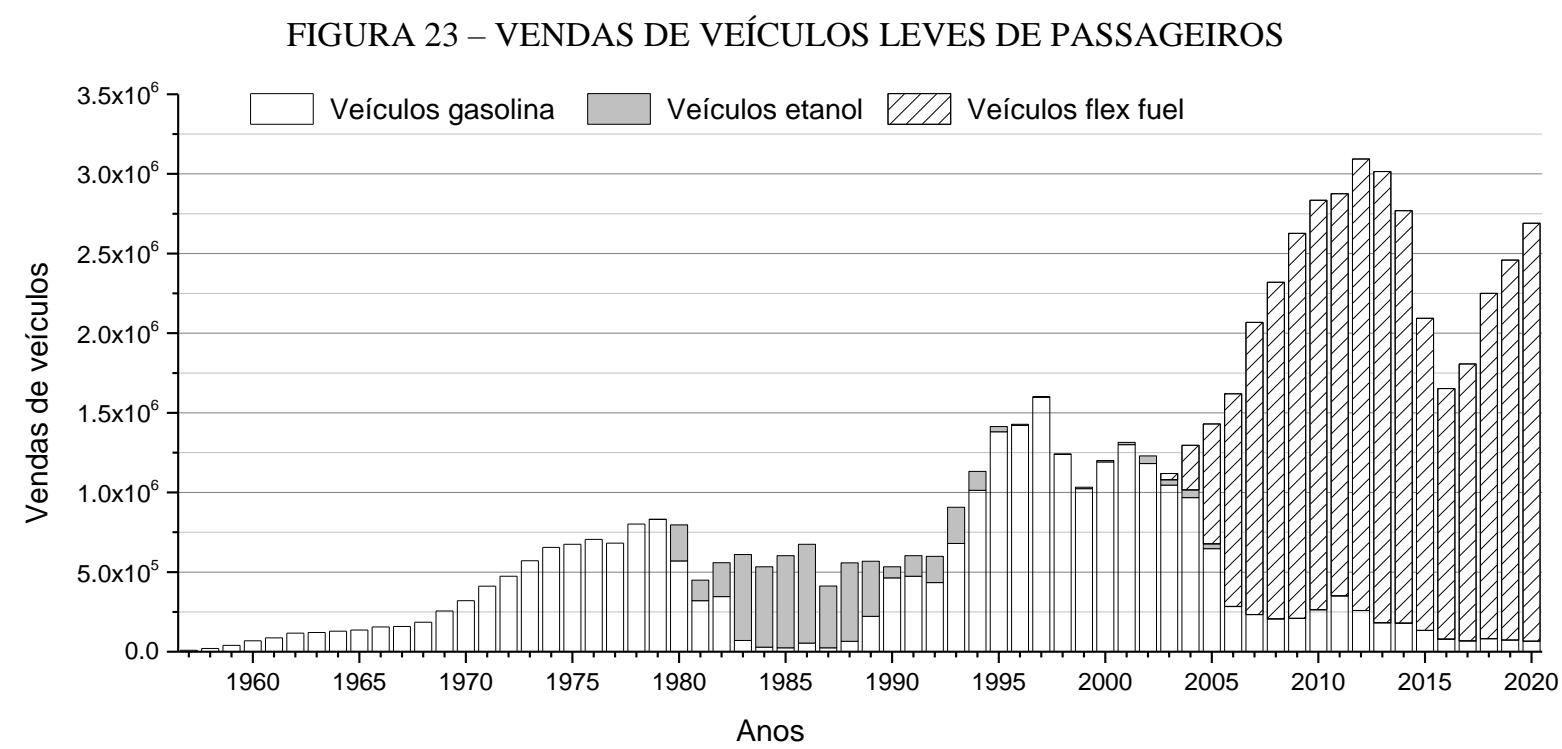

FIGURA 24 - VENDAS DE MOTOCICLOS

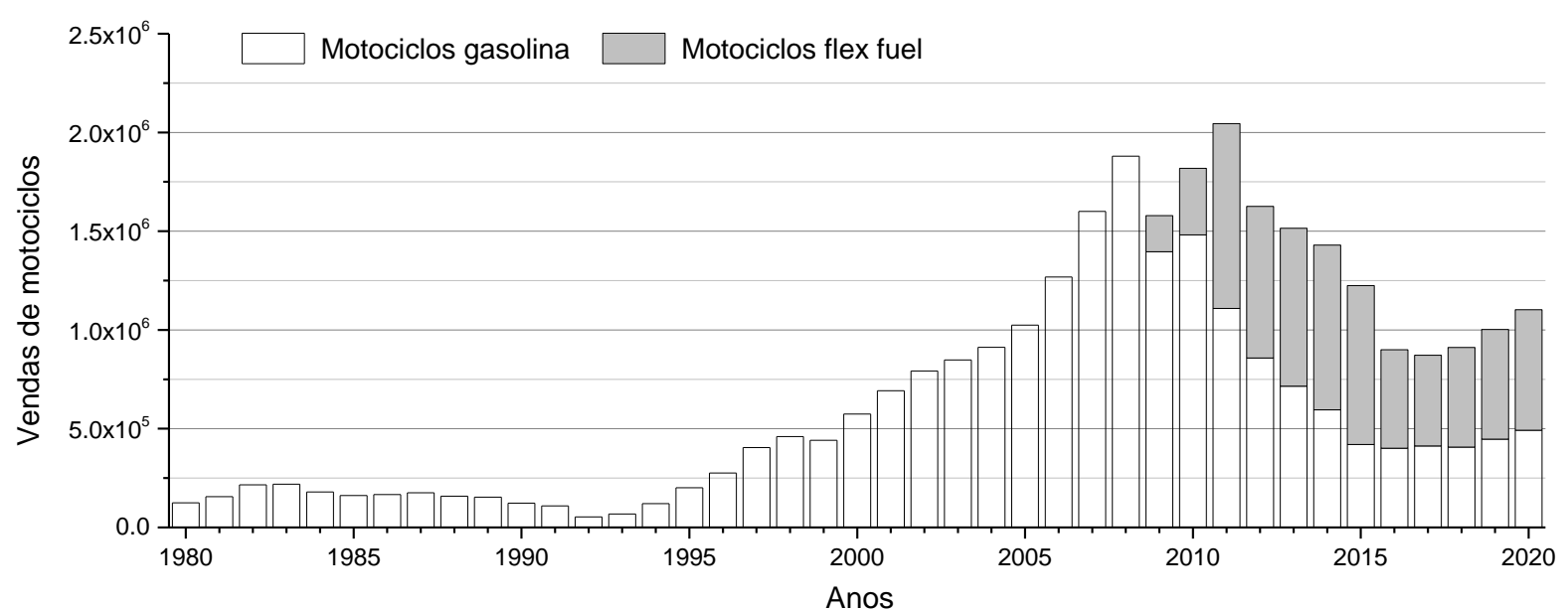

